の方共でつ地同制＼cjkstart明をこ市

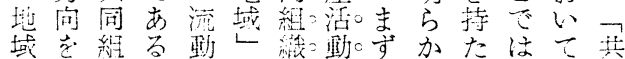

的子織口的ことをるなな其種同

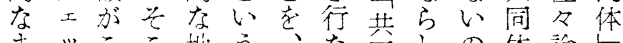

まッここ坮う、な浻しの体猃

上7のに域のそつ体めで論議な共

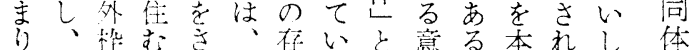

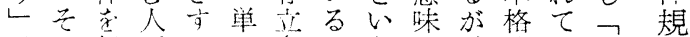

での超びのに条一。うに、的い共制

あ傾えと厄共件定去お本にる同々

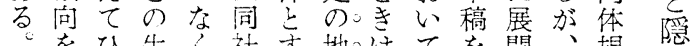

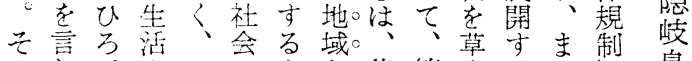

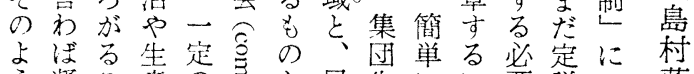

う㠜こ库の志亡居生にに要説つ落

な集との外志思住活こあもををいの

ま的が場枠导わ及心のたな得て特

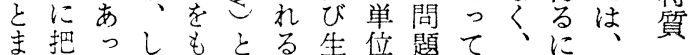

りえてたっい。産たにのまい経

は先名たうこのるふいたた済

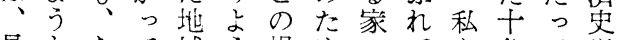

具々なて域う場め斿てな分て学

体寺扔そのな合のがみりにいや

的るかのま無口種定。たのそな社

につつたを限二々住い視のい会

は一そめま定定のし。点用的学

こ定ののり加の共生。を意こに

隠

岐

島

村

落

の

共

同

体

規

制

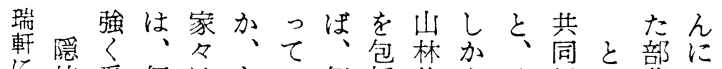

飞岐受個はあい個括牧もそ組こ落亏

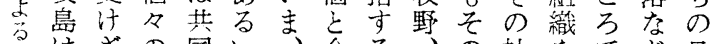

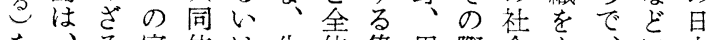

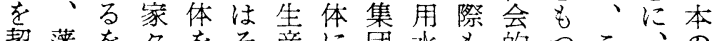

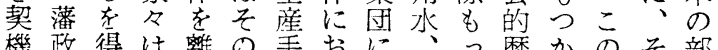

機政得は離の手おに部

と時な共れ用段けど漁と更と一の落

し代く同て益のるの場も的心定典や てのな体はを主生よな基発う地型村 に期での活ぐる手にの的段之の兒と 商市依しっも段配所な階は蒙出く 品日乃存生てのの分有こに它に 経本う性産共が所さ権々沈そがこ鈴

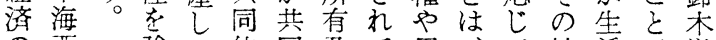

の酉強得体同及て用、て地活が栄

洗迴めな无体びい益主種域及出态

礼航優全用る権た令のび来郎

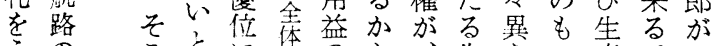

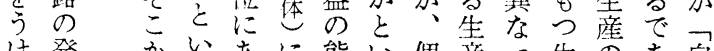

け発吕いあに態い個産っ生のあ自

た見らうりょ様う及手て活たろ然

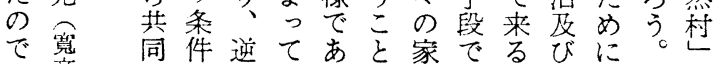

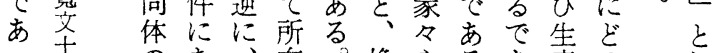

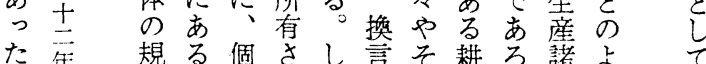

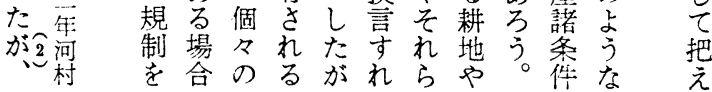

栄

市 


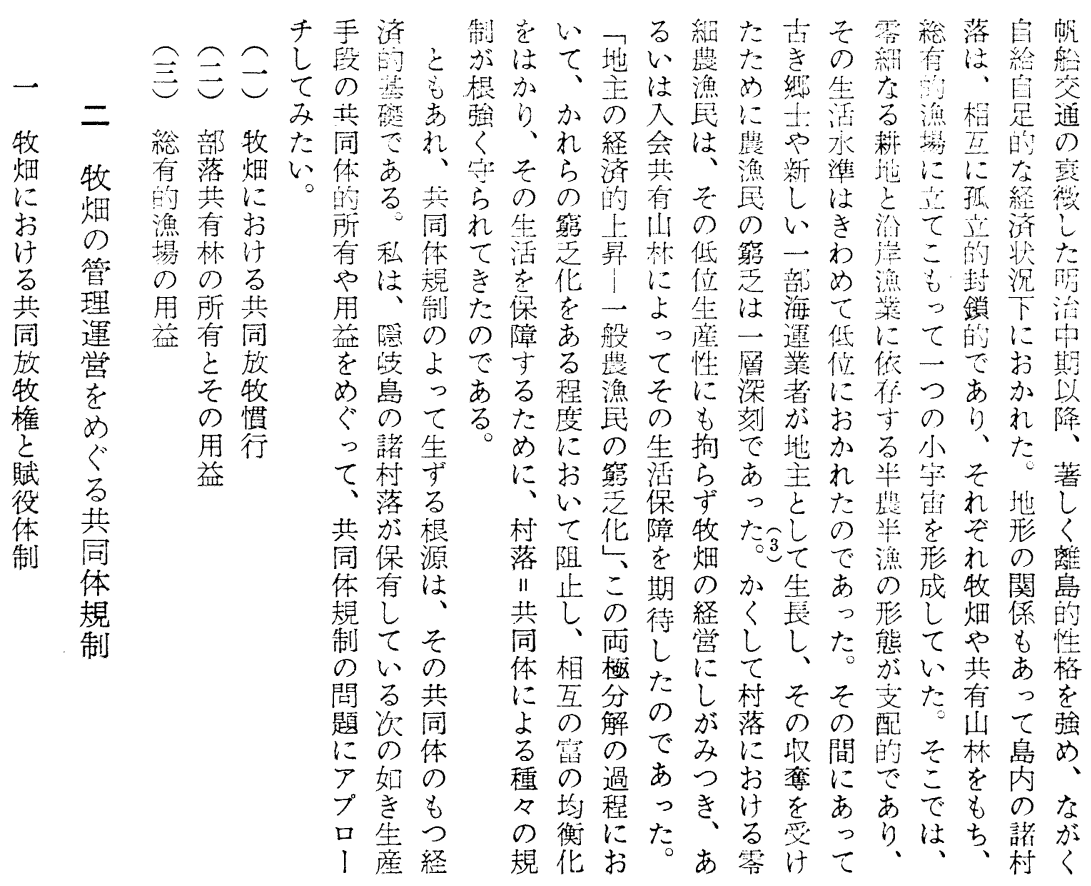

作るり

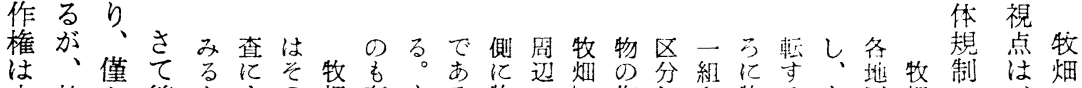

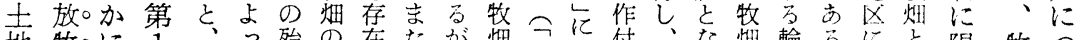

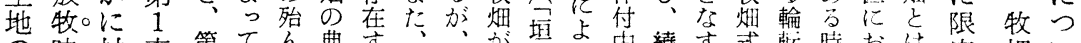

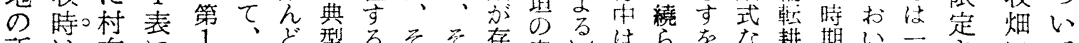

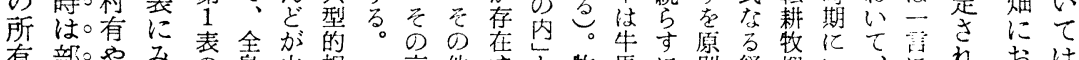

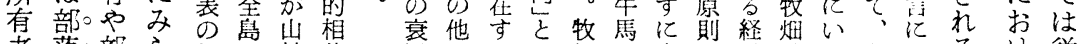

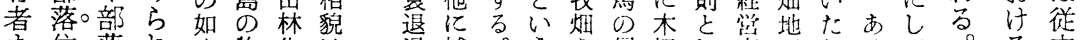

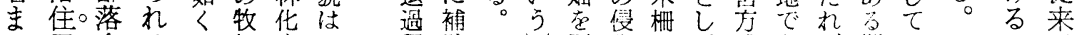

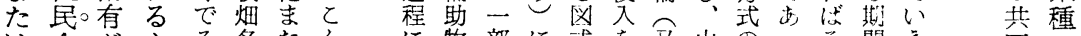

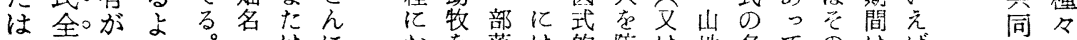

小体。あう。・はに

作の。るに面㬐ち

人共。。程通で

に同し二放化

あ使。たれ牧し島

る用。がら牛て前

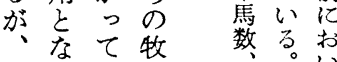

放る耕。畑

牧の作。の

権では。殆

はあ個。ん

土る人。ぞ和ら

お存落は的防は地名てのはば

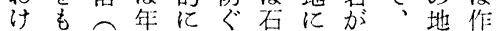

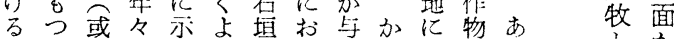

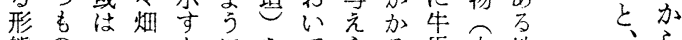

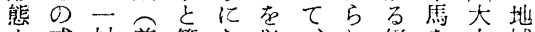

它或村普第な以机経芷尔域

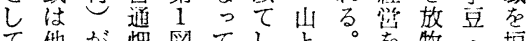

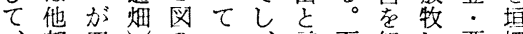

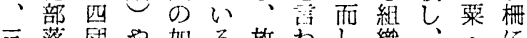

使いて

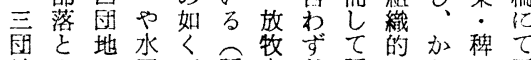

角まし 地の田で隠虫谷隐汃加、 区

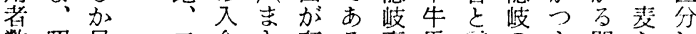

地。別。杜和背

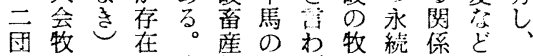

所古に私

有な行有

のわ地

有ちわで

所四古

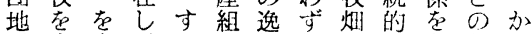

㤫年

者数牧島

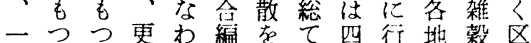

団毛 0 亿古防を区な区分

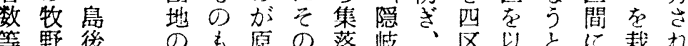

無耕れあ

のも原の落岐、区以比栽机

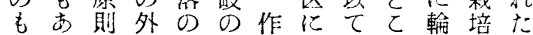

放の

₹ 研

れ究

をさ

可礼

能

な竞

L w

め

る 加先

$め=$

のこ

共で

同の 
牧畑の現 状

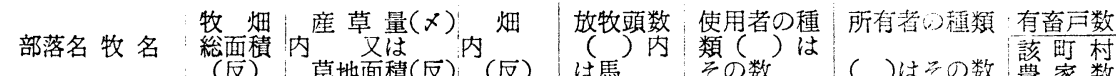

( )は只の数農家 数

(島前)

布施須賀高峯第二 $\quad 675.5 \quad 13.8$ (反 （中牧）

(丹後牧)

(補) 唐橋牧 215 .

東：（Ｉ）高木牧 2,690

豊田( 11$)$ 長井牧 452

中里( 11 ) 横手牧 224

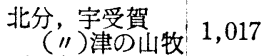

西の島町浦郷

由良牧 1,943

１赤尾牧 $1,775.6$

" 老屋牧 $1,836.7$

" 長尾牧 $2,196.7$

"I 中牧 $1,105.7$

" 小牧 593.8

"美田 上具牧 311.6

" 上の牧 196.7

" 犬牧 163.0

" 後山牧 214.8

" 宮谷牧 9,391.0

" 宇賀 先牧 122.8

" 済牧 256.1

" 自浦牧 203.0

" 135.9

" 別府 中牧 73.2

" 耳坪牧 107.3

" 中床牧 103.9

" 北谷牧 116.4

知夫村 東牧 580.6

" 中牧 $1,223.0$

"

" 居屋牧 1,291.6

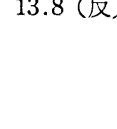

草地面積(反)

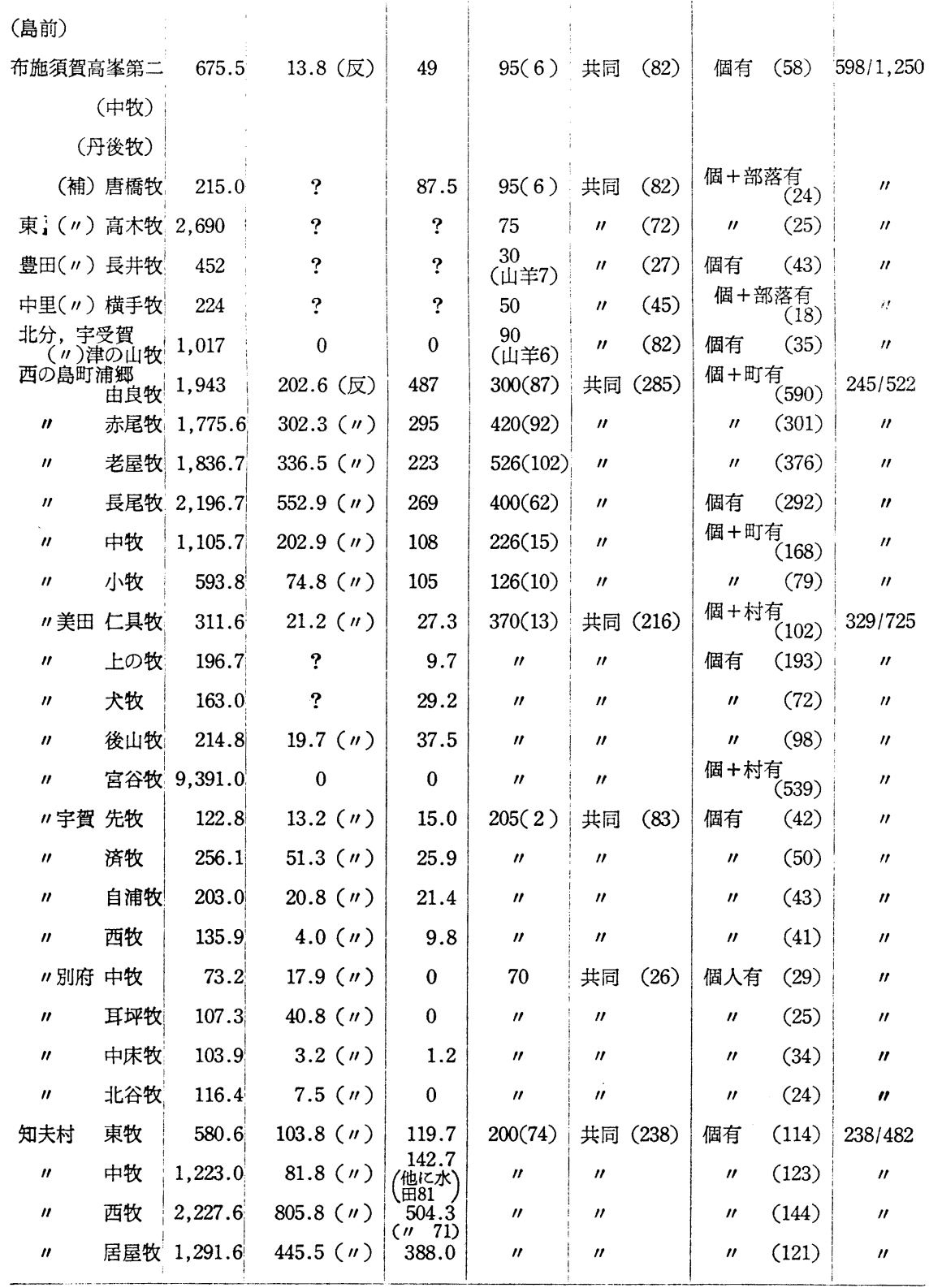


第 1 表隐岐

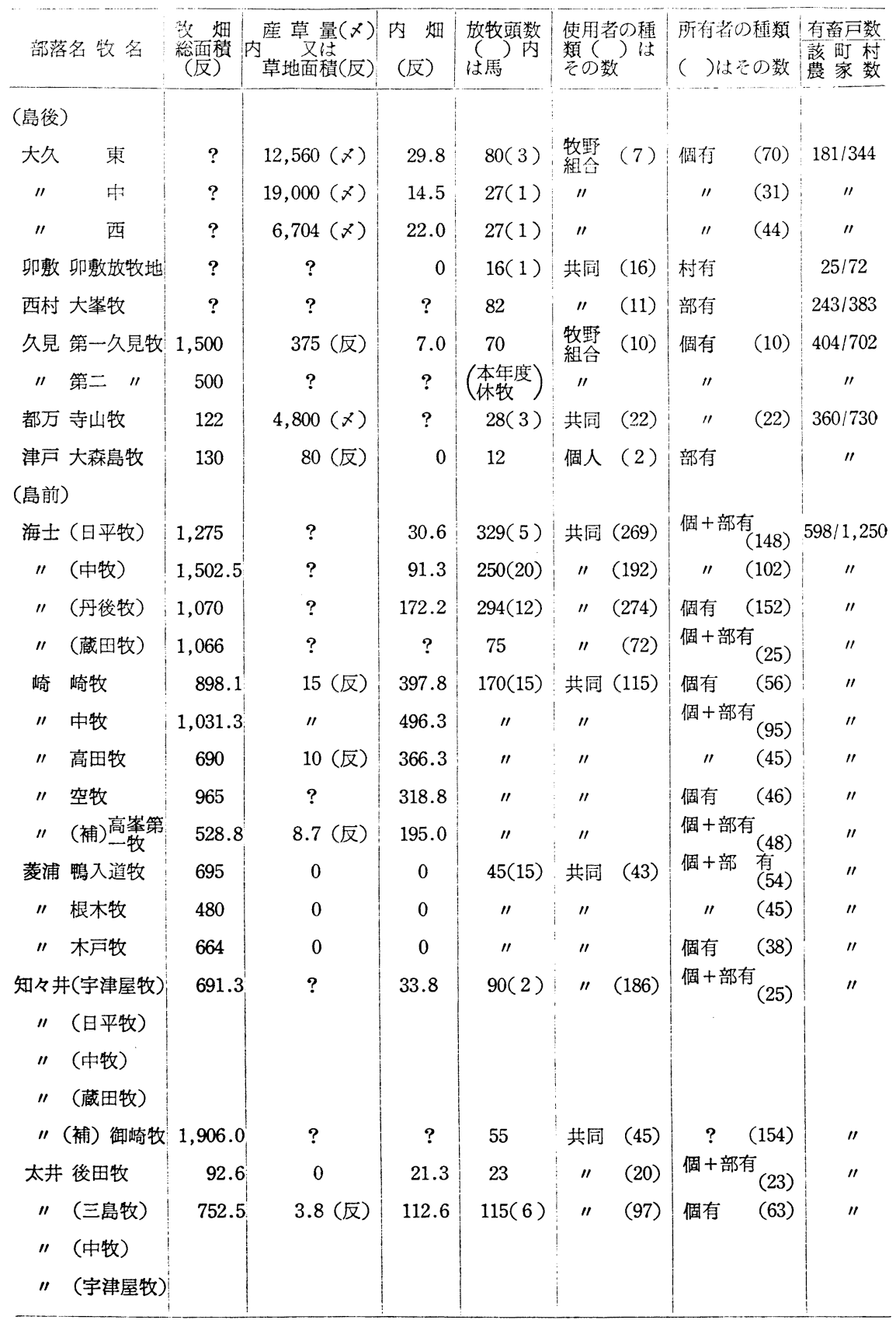

（注）(1) は他部落との入会牧野 (2) 個有は個人有, 部有は部落有をさす 


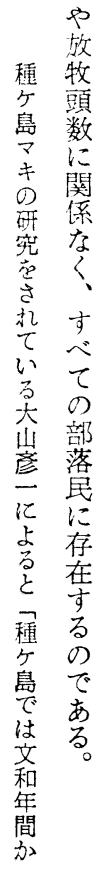

第 1 図 牧烟の形態
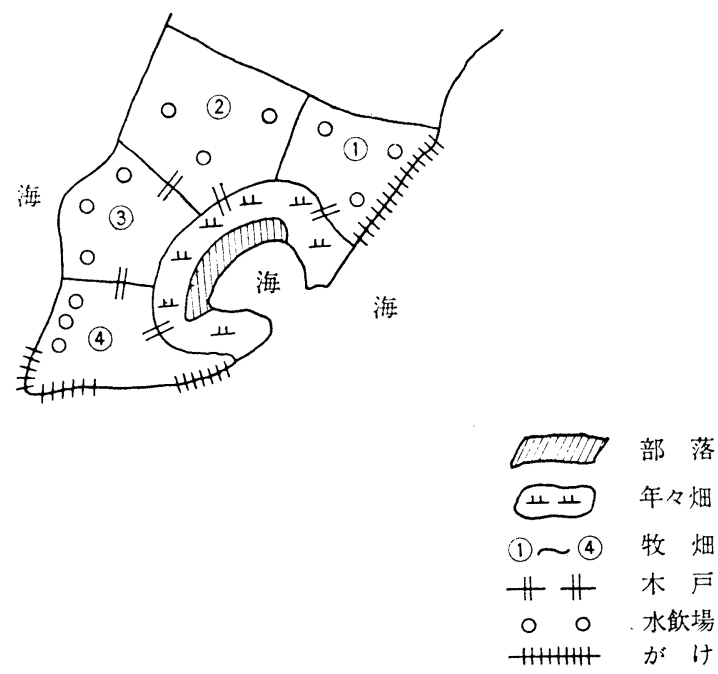

付く片た関は作れ部

と放ので索はた落さ第にい史畑畜岐て会科農増ら し 牧士ある個個もにて 2 お

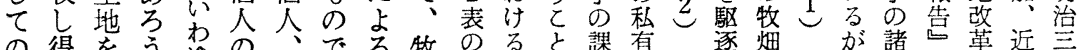

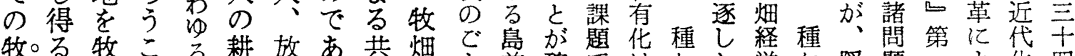

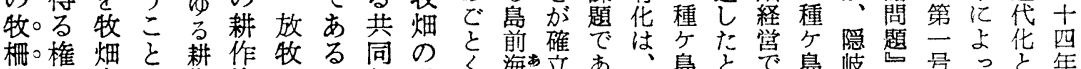

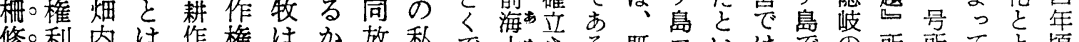

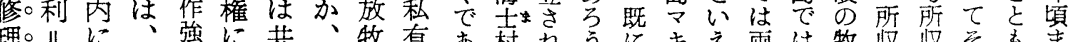

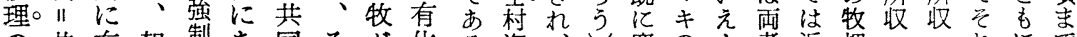

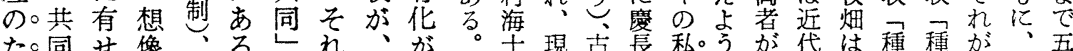

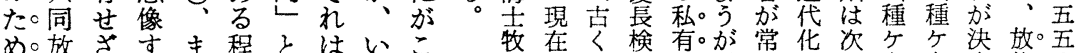

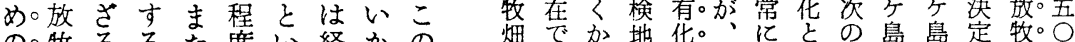

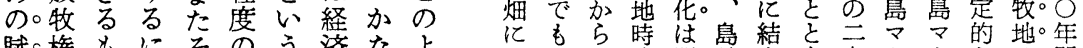

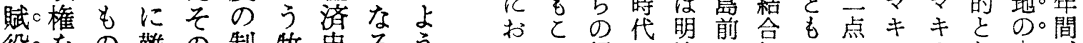

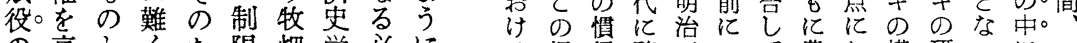
の。享とくた限畑学必にる慣行確兰つて農お構研っに。、 負。有雖なめを経の要早種行と立十いいとい造究た農。キ

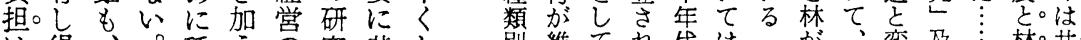

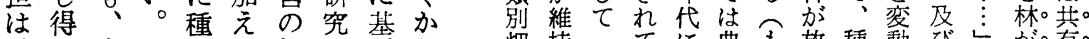

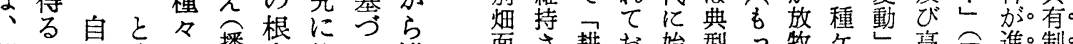

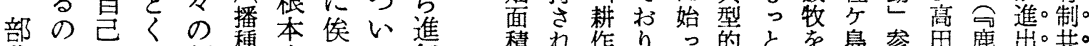

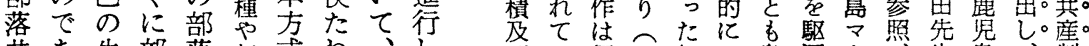
共あ牛部落収式ね、し び個乞如と島逐キ祭生島、制。

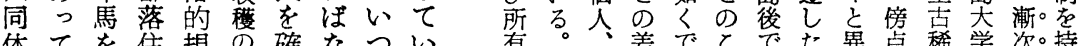
体てを住規の確なつい有。差でてでた黄点稀学次。持 の、頭民制時立ら頃た桨い放買あとはのなは祝文私。続 規そ数たを季守な加涭洗ま牧のるが、でっ筆賀理有。し 制のにる必品るいら岐学度解がい農あて者墖学华た と反関以要毠たが開のる慶共は隠る林がると﨎紀行か

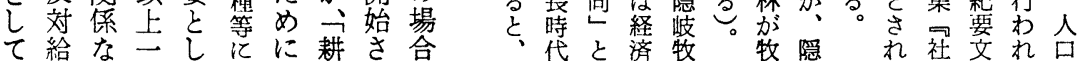


第 2 表 海士方牧における種類別畑面積表

（慶長 18 年検地帳による）

(単位反)

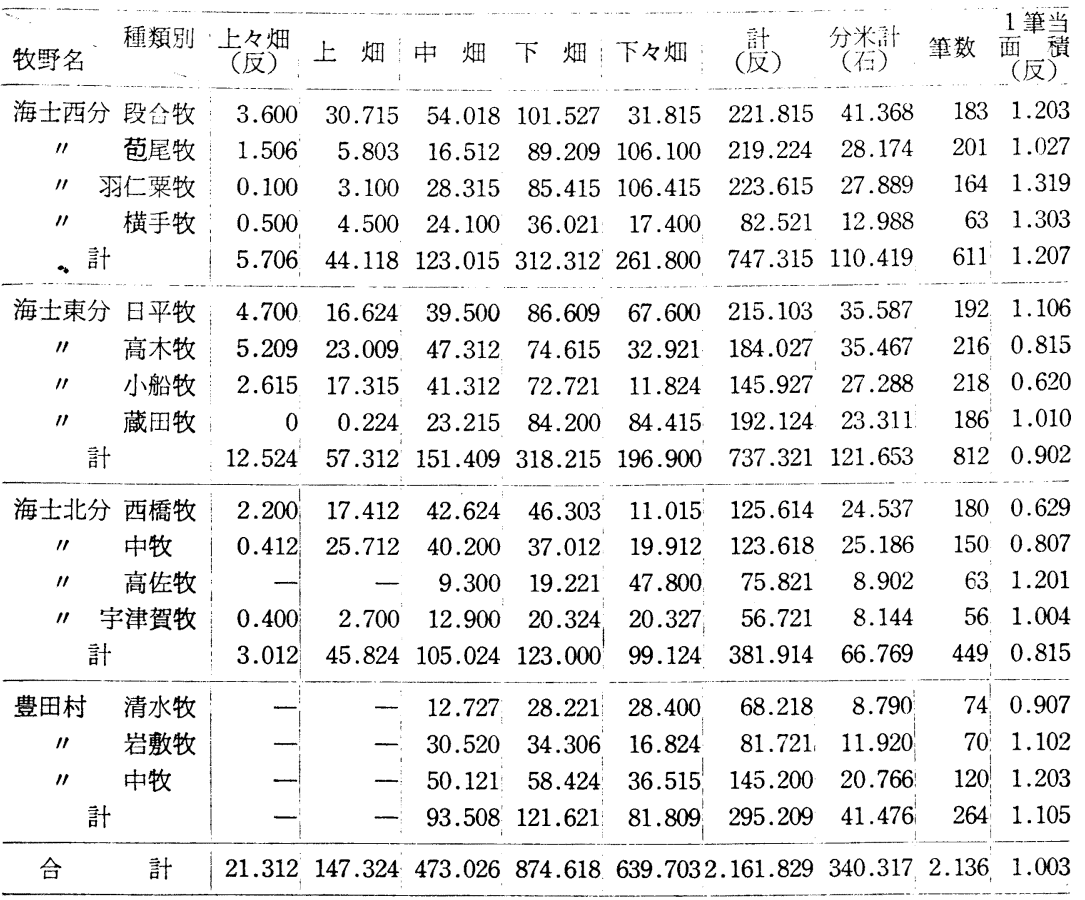

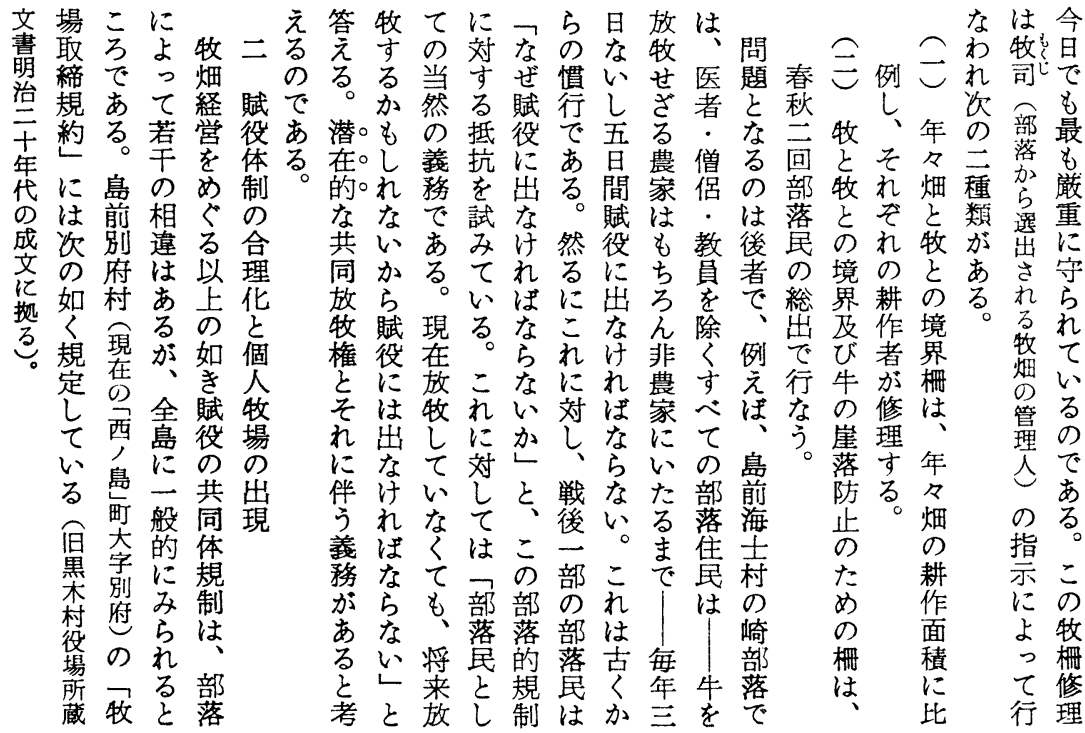




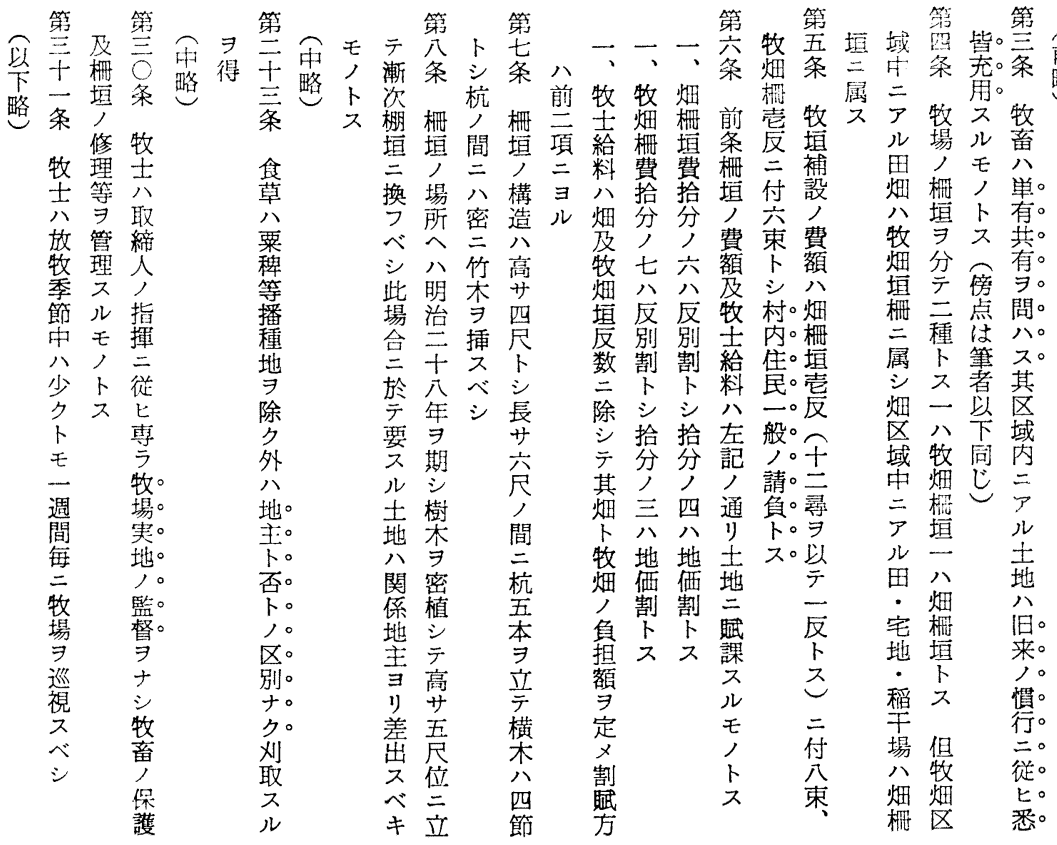

有も可围しも規このしえ抵化よ最めをを民出のを 者つ能这ての制さの経て多抗でっ近に法合全役海除多

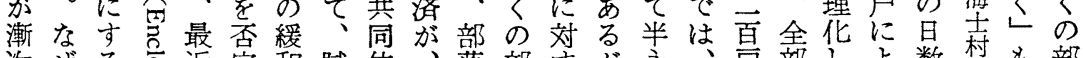

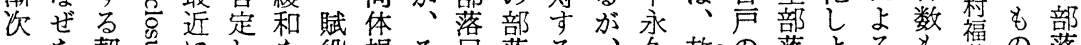

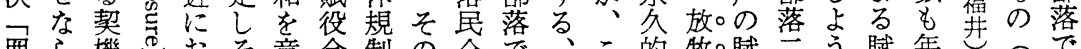

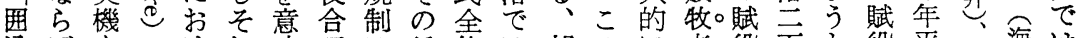

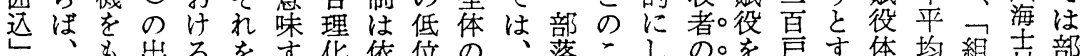

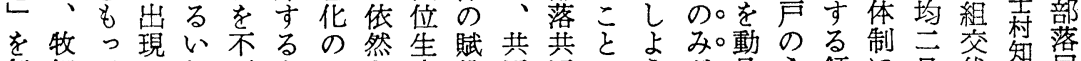
行畑てはわ可もこ之産役同同はう出員う傾に旦代等民

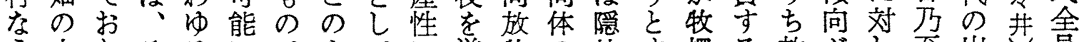

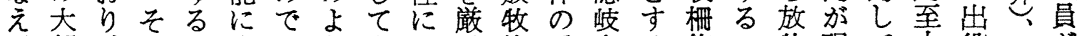
ぼ部、のつ军あう生も重権妥島る修こ牧現て去役方 分牧究個るらな拘に熟協近試理々者わは日来出 土吕畑極人条、傾続ら要受之代みのは独前のと住役 地私経守牧件そ向け导求乃適化も賦、僅て記 すす六卞 な有営る場とのはる牧し至庍にな役そかきのるるかる

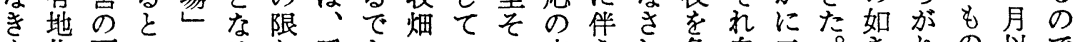

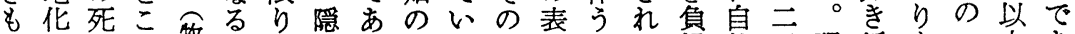

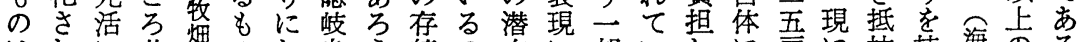
はれに共烟のお島う緢の在に部いしに声に抗持海のる

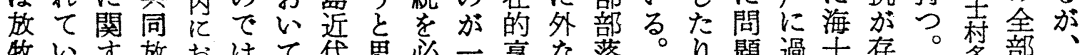

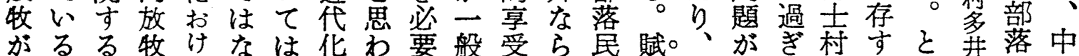

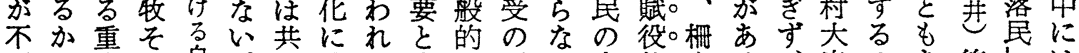

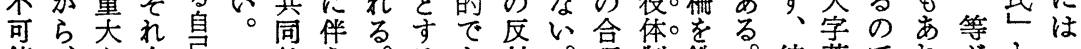

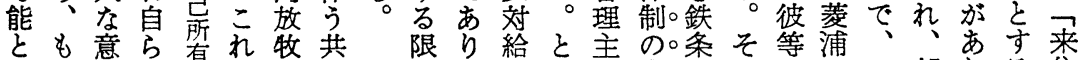

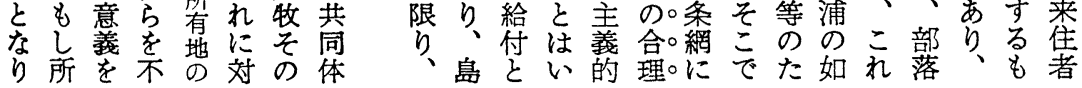


第 3 表 㑑人牧場所有者（知夫村仁夫里部落, 昭 32.7 . 現在) る。作そ牧。同

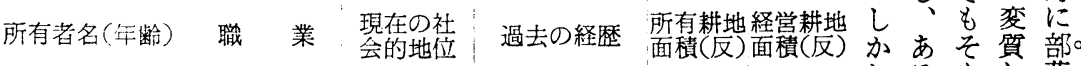

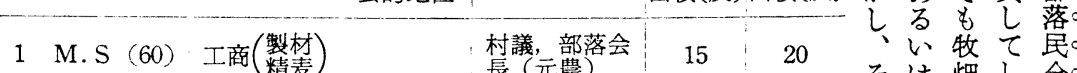

長 (元農)

2 M.U (40) 農 村農業委員 部落会長

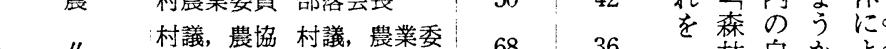

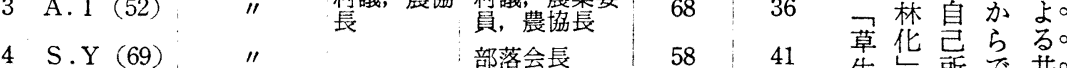

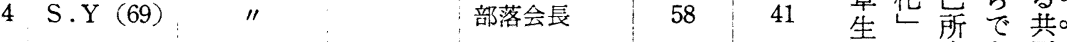

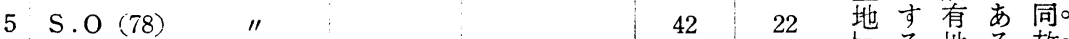

6 Y.K (37) " $11 \quad 11$ まこ地る。较。

7 H.F (44) " $\quad 63 \quad 31$ たと祭は

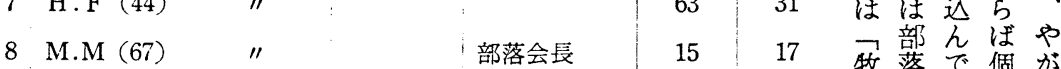

9 H.S (73) " (長子)部落会長 $43 \quad 20$ 場注そ华て

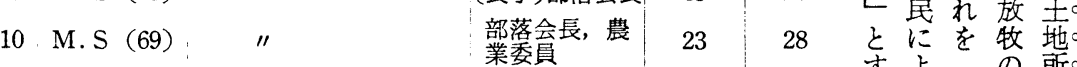
すよフの 所。 るっ年現 有。

放自共なるに害込そとにれ場明る行るてくとて々況者。

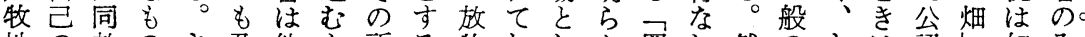
地の放のさ及他と所る牧おしか用わ然のとは認如如み。 に牛牧にらぶの有水牛りてに込れる慣い囲さと何の。 放を期なにの放そ者飲の、経個みつに行う込れし。個。 方共にる悪で牧の染場必営人しつ最でのをてて人。 同はと質あ者被囲を要くさ牧はあ近あが解い耕放。

かて部力るる規のらをあ牧も場を導加な存のるそ れい落関。個甭制維かはる場のの契くとすいし農こ事の

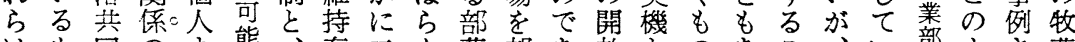
はも同のま態近存三ん落部あ放とのあこ、い部よさ草 多の体地たに近続うでで落る方しでれと隠る落うえが かはの域は牧法"のいはの。市個を岐命村なあな

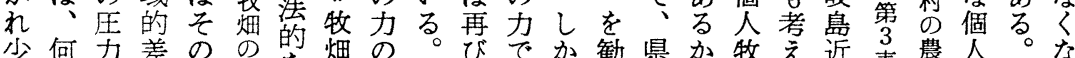

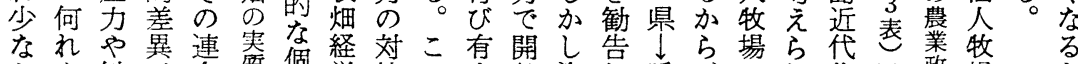

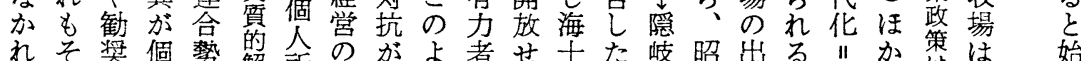

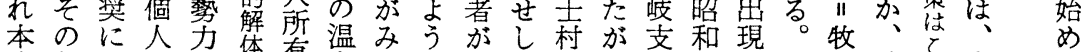

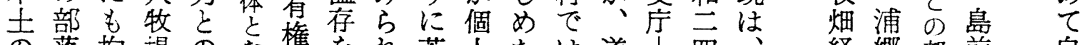
の落拘場のな権をれ若人たは遂】四、 市のらの対竟はる貫牧例加知年伝

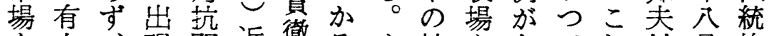

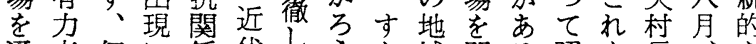
通者個に集代ような域開る昭を長、な

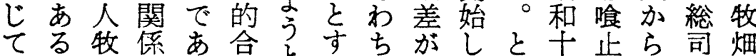

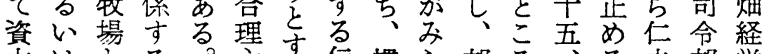
本はとる。主方伝慣ら部う六る夫部営 主々しとこ義る統習れ落が空こ部并川 義のてみの的々的法ると最年々落上共 経連囲て二。なのな的がの近頃㤎洛顧同 済合込よつ。主結力な、間同三で対問放 機樊みいの張果"共こにし箅きしの牧 構力を。社"I共同こ緊海所な子牧を とで行事会。有共同放に梫士の個畑崩 密あな実力。力放体牧は関森個っ人調買 接りっ、の。な牧の権明係の人た牧査に

経鄉部前

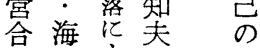
理士よ村 囲 化にての込 のそ牛仁 地

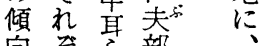
向 そ部

々れれ落自。 共一る星。 に例六君 の。 今㤎方数牛。 後吉に○、 み。 徐る十同を 々 箇同村放 に市所第牧 増き現第守 


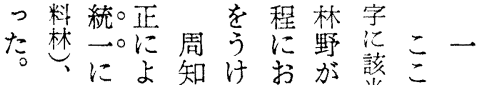

換あ向っのていて当るた嗳

すいら-くるくに是自

れはれ時明吕共ち方村

ぼ絶、的治、同いな专落

ᄀ対国後以之受加わるの

入主蒙退後い真なちの共

会義権法のう者る私は有

㷊的力あわ点た形が、林

野官とつがにる態前主

に龙そた国つ部で述と

対機のとのW落管 $し し$

京構頂し山て民理たて

るに点て林では運共旧

農よたも政あ、営同幕

民るる、策る部さ体時

的收皇一注。落れが代

利奪公 貫

共て所の

用港し明同以有村

を府よて治

排県る部。十

体るし

除林囲落。四

し町込有。年

あ村 国林。の

る㷊有野。森

はで禁。法

王あ御理。改
加吕享 明

らそ受治

加して 村

なてき制

るとた 後

規の大の
るよ役牧にす自こてえに

てる合畑対る給のいて結

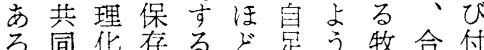

放しに批是的な畑理W

共占牧の対判まな批経的て

有考 II傾す的た離判営にい

林え賦向る高㩊島やに生る

のる役や䶊ま岐的抵詨虐の

管口に旦り島後抗し力で

お讲の、自焦のての市

る込意個体性表は去る

営共店牧生脱で判登飞

古のき場産却あ的展の

め体事わは力しるでを限

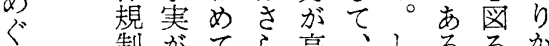

制阮て ら高、儿るろ方

仕あ強にま本た共うれ

共 るく䧻れ主が用とら

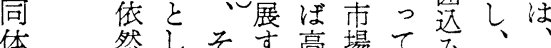

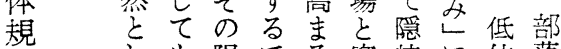

制しも、限でる波岐に位落

て、りあほ接島よ生共 存部、ろどにのる産同 続落一门、結経個性体 し民部。牧合济人にの 機全にし畑守吕牧停染 能体つ加経れそ場滞を すに賦し営ばのはし超

三る島よの带八及く県後くく、過めの縮

年部るい要そ第根る諸と三びむた進、、、程6、過さ

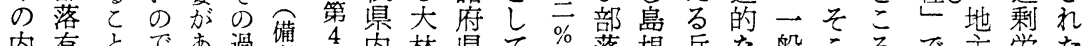

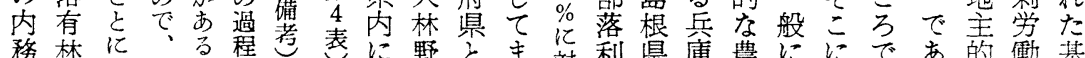

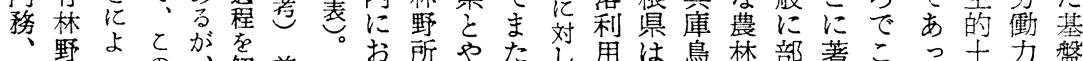

曲野っの智前お所やたし用は鳥林部著こっ土力盤

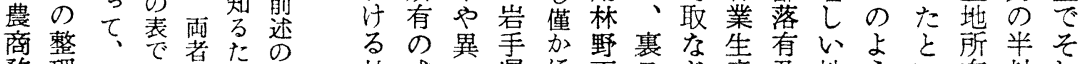

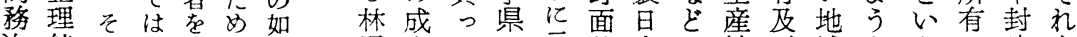

次統の公区にく野立ては二積本は地び域なえの建を

官一逆有別は、所々心名立のにそ带部差過る中的再

連|の林し部山

名山之飞落林

有樑る手比おので落を程

形いと制 率汁代あ利見は

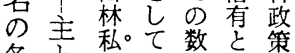

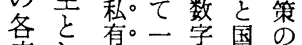

府し化。括は基

県 $て$ の し 明県調

知町集。た治市、

事村行。四市市

宛有觉とさ町部

通林罢で年有䒴

牒野のは以林

$\neg へ s^{\vdots}$ 公後存野

の目有で対の

切的林な照整

特替でのい的理

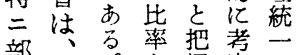

部、る。握等で

落明比㜪察す

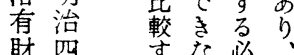

態関こ度こ方る表る用る

の連ろ地の極後的文のこ全

推をで带こめ隻な考林々国

移有あと元的を野加二

を古るるしは低なのら出出律

みる纪森低農でれ今来な

るもと士㷊い㷊ある昆る捕

とのさ地氏鳥業ろ。な。度

に搾編

お取成

でれ所が取地う東お森で

なあて有泉缼域。北多出進

おる到の島晋で然諸く広行

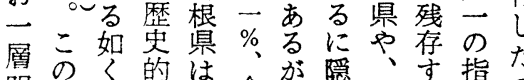

る基し

林 盤 農

野々業

所した

有た将

の山で

比経生

重営 活

を考出

漸 徐 来

次々な

明こ、、過株全架隠牛る摘の

確々鉄程小西部島馬の商で熟細

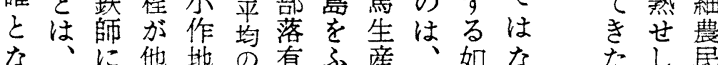


第 4 表 島根県における所有形態別林野面積（明治 33 年:現在）

\begin{tabular}{|c|c|c|c|c|c|c|c|c|c|}
\hline 市 & 郡 全 & & $\begin{array}{l}\text { (A) } \\
\text { 公有㷊 } \\
\text { (町) }\end{array}$ & $\begin{array}{l}\text { 社寺林 } \\
\text { (町) }\end{array}$ & $\begin{array}{c}\text { 私 有 林 } \\
\text { (町) }\end{array}$ & $\begin{array}{l}\text { (B) } \\
\text { 就 } \\
\text { (町) }\end{array}$ & $\frac{\mathrm{A}}{\mathrm{B}} \times 100$ & $\begin{array}{l}\text { 昭和 } 21 \text { 年: } \\
\text { の比率 }\end{array}$ & 梦 \\
\hline \multirow{7}{*}{$\begin{array}{l}\text { 出 } \\
\text { 雲 } \\
\text { 部 }\end{array}$} & 松江 & & - & 0.3 & 19.0 & 19.3 & 0 & 14.9 & \multirow{7}{*}{ 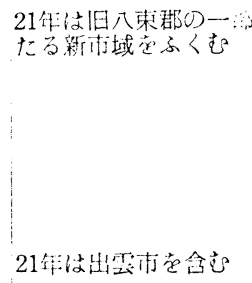 } \\
\hline & 八 & 束 & $5,221.6$ & 245.6 & $17,428.3$ & $22,895.5$ & 22.8 & 17.4 & \\
\hline & 能 & 義 & $4,284.2$ & 276.1 & $19,824.4$ & $24,384.7$ & 17.5 & 14.5 & \\
\hline & 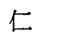 & 多 & 474.5 & 412.0 & $31,563.0$ & $32,449.5$ & 1.4 & 1.7 & \\
\hline & 大 & 原 & 649.0 & 29.2 & $10,536.0$ & $11,215.0$ & 5.8 & 8.9 & \\
\hline & 飯 & 石 & $2,593.4$ & 188.6 & $50,172.3$ & $52,594.3^{\prime}$ & 4.9 & 9.6 & \\
\hline & 樰 & M & $4,843.0$ & 151.5 & $18,516.5$ & $23,511.0$ & 20.6 & 22.4 & \\
\hline \multirow{6}{*}{$\begin{array}{l}\text { 石 } \\
\text { 見 } \\
\text { 部 }\end{array}$} & （邇 & 摩 & 376.4 & 125.9 & $9,637.3$ & $10,139 \cdot 6$ & 3.7 & 5.4 & \multirow{7}{*}{ 21年:は浜田市をふくむ } \\
\hline & 安 & 濃 & $1,958.3$ & 54.7 & $5,552.6$ & $7,605.6$ & 25.7 & 16.2 & \\
\hline & 尼 & 智 & $4,662.6$ & 59.7 & $38,900.3$ & $43,622.6$ & 10.7 & 3.2 & \\
\hline & 那 & 賀 & $1,743.6$ & 394.9 & $35,340.5$ & $37,478.4$ & 4.6 & 5.7 & \\
\hline & 美 & 濃 & $22,193.9$ & 77.5 & $32,528.3$ & $54,799.7$ & 40.5 & 20.6 & \\
\hline & 鹿 & 足 & $2,696.8$ & 31.7 & $6,155.7$ & $8,884.2$ & 30.4 & 6.6 & \\
\hline 隠 & & 岐 & $1,250.7$ & 16.8 & $3,414.2$ & $4,681.7$ & 26.7 & 23.8 & \\
\hline
\end{tabular}

（注）両年度の島根統計書により作成

態常属野総六しぎのるり、比のいは林根主等お本了

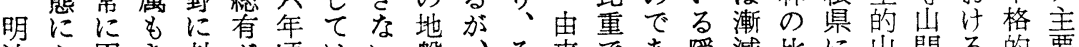
治ふ困き対加頃はい盤々そ来であ隠減比に山閏る的要

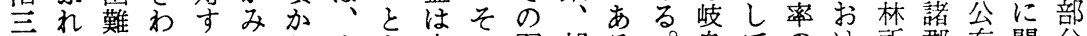
九てでめるらら大さ市の弱部る。島ての所所有開分 年みあて部れそ正れ町過点落。問のい高る有に林始夕 七よるあ落るの寿た村程にの 月うがい是に政期このに乗入 島。ま口い策以之所お荟 狊根こい所たに降を有いて山 県ので有っ修各あでて入野 訓こあ意た正地っあ、会に 令々心識。茷にたっい地詨 第をたにこ加農。てわの索 四前。はの氐こ、ゆ整る 十提し濃よらのの部る理農 号とた淡うれ抵よ落入統民 公しががな抗うは会方の 有てっあ経再運なた公事所 林、てり緯ひ動政た権業有 野隠正、が入㤎府そ説架意 整岐確まあ会起のの乼識 理島なたっ林り統地主めは 規のる林た野、二上張らき 制部統野たにそ整権されわ 第落計のめ対の理をれてめ 共的所、守結の有部きて 条10 有把有部る果強卞部た薄 に林握権落部落る落の弱 よのはの有落昭にに有でで り実非帰林の和対す林ああ

題みるか鑪拉の野さル はは架っ経”焦いのれ林 こい箥諸営を極積のヨ のず川郡 "物度比で市 公れ・に鉄語に率あ町 有も美お師る低はる村 林三濃いのもく、が二 中○のて存のな仁、統 い\%両も在で?多明 わ以郡、にあて。治帰 ゆ上飞昭起りい大严属 るの、和因、る原至

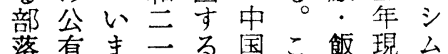
有林わ年娄山石在儿 林をれまの間は。にコ の残わでで地い遇お卜 も存れのあ带う摩い 性し問間る。 格め題そ当々も賀島に とてとの時くな根よ そ心し比公にく啹県っ 
第 5 表 部落有, 町村有林野面積（明治 39 年現在）

\begin{tabular}{|c|c|c|c|c|c|}
\hline 町木 & & & 极落有 & $\begin{array}{l}\text { 町 村 有 } \\
\text { (町) }\end{array}$ & 所 有 部 落とその 面 積 \\
\hline 西 & 郷 & 虾5 & - & 184.00 & \\
\hline 東 & 郷 & 村 & - & 13.34 & \\
\hline 中 & 条 & 村 & 103.94 & 3.44 & 原田 (25.88) 平. (18.32) 有木 (58.88) 池田 (0.86) \\
\hline 磯 & & 村 & 48.75 & 8.43 & 下西 (48.75) \\
\hline 都 & 万 & 村 & 340.88 & 168.09 & 都万 (234.89) 津戸 (36.82) 那久 (37.62) 油井 (30.65) \\
\hline 五 & 筐 & 村 & 107.48 & 39.38 & $\begin{array}{l}\text { 山田 (0.50) 那久路 (3.71) 代 (78.50) } \\
\text { 苗代田 (13.78) 久見 (10.99) }\end{array}$ \\
\hline 中 & & 村 & 102.87 & 107.08 & 元屋 (26.84) 中村 (64.05) 伊後 (11.98) \\
\hline 布 & 施 & 村 & 117.34 & 83.16 & 布施（117.34） \\
\hline 黒 & 木 & 村 & - & 454.75 & \\
\hline 浦 & 郷 & 村 & - & 32.76 & \\
\hline 海 & \pm & 村 & 171.61 & 41.98 & $\begin{array}{l}\text { 布施 (17.80) 崎 (44.65) 福井 (24.08) 宇受賀 (8.63) } \\
\text { 豐田 (16.40) 知々井 (63.56) 太井 (2.24) }\end{array}$ \\
\hline 知 & 夫 & 村 & - & 120.00 & \\
\hline & 訪 & & 992.87 & $1,256.41$ & \\
\hline
\end{tabular}

（注）県庁所蔵文畫による

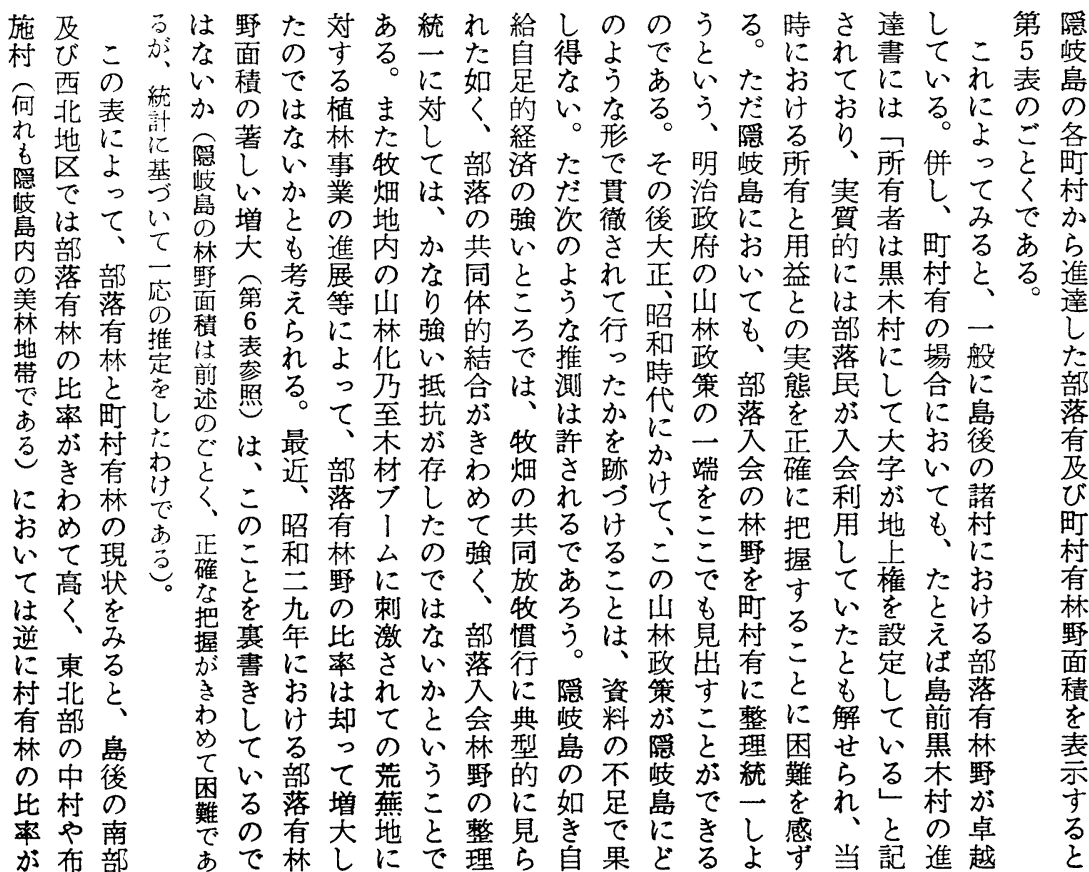


体け林町高

規るは村い

制大牧有

の久畑の島

問 地比前

題加 の率に

に茂山はお

アの禁極い

プ三で度て

口部あには

澡子低林

于案解々野

乙出 抽私

みし、有杂

た、る化少

、主。影著い

た題以著心

る上立方浦 郷 町

只前進そ

共提行の

有标定中

野立て活い

をてる证

ぐ島と部

る後私落

共に有有

第 6 表 部落有, 町村有林野の比率（昭和 29 年）

(単位 $=$ 町)

\begin{tabular}{|c|c|c|c|c|c|c|c|}
\hline & & & $\begin{array}{l}\text { (A) } \\
\text { 林 野 総 } \\
\text { 面 } \\
\end{array}$ & $\begin{array}{c}\text { (B) } \\
\text { 部 落 有 } \\
\text { 林 野 }\end{array}$ & $\begin{array}{l}\text { (C) } \\
\text { 町 村 有 } \\
\text { 林 野 }\end{array}$ & $\frac{\mathrm{B}}{\mathrm{A}} \times 100$ & $\frac{\mathrm{C}}{\mathrm{A}} \times 100$ \\
\hline 西 & 郷 & 町 & 5,279 & $2,806.25$ & 111.91 & 53.1 & 2.1 \\
\hline 都 & 万 & 村 & 3,394 & 889.57 & 127.21 & 26.2 & 3.7 \\
\hline 五 & 䇢 & 村 & 3,894 & $1,086.35$ & 20.57 & 27.9 & 0.5 \\
\hline 中 & & 村 & 1,821 & 102.00 & 354.00 & 5.5 & 19.5 \\
\hline 布 & 施 & 村 & 1,574 & 1.00 & $1,040.00$ & 0.06 & 66.1 \\
\hline 黒 & 木 & 村 & 2,803 & 97.44 & 213.99 & 3.5 & 7.6 \\
\hline 浦 & 郷 & 町 & 451 & 1.53 & 14.95 & 0.3 & 3.3 \\
\hline 海 & \pm & 村 & 2,119 & 105.78 & 16.15 & 5.0 & 0.8 \\
\hline 知 & 夫 & 村 & 724 & 20.35 & 15.30 & 2.8 & 2.1 \\
\hline & 計 & & 22,059 & $5,210.27$ & $1,914.18$ & & \\
\hline & \multicolumn{7}{|c|}{$\begin{array}{l}\text { (1)西郷町は旧西郷町のはか,, 旧東郷村, 中条村, 僟村をふくむ } \\
\text { (2)林野総面積は昭和 } 24 \text { 年 } 1 \text { 月 } 1 \text { 日農林水産業調査結果に拠る }\end{array}$} \\
\hline
\end{tabular}

同お山

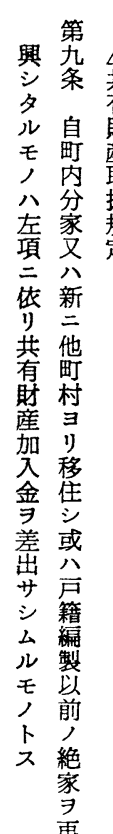

長外に傾と産た得育る以管の制こ林各一 時来入向し落る費収前理が定の|十町西

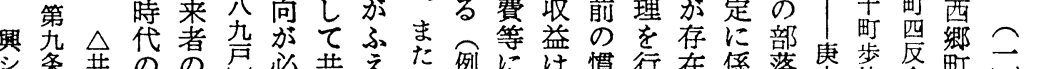

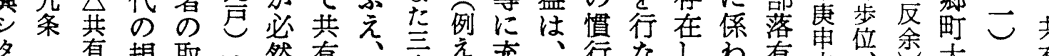

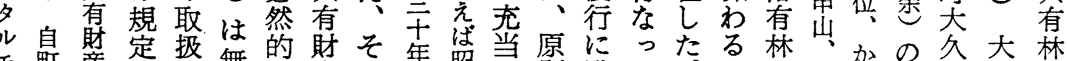

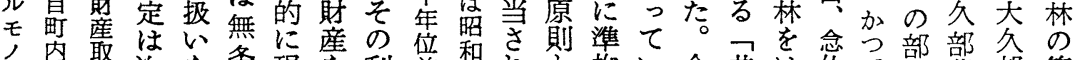

八分报次を条現を利前和れと拠い今共は仏て落落部管

の如件わ享益飞几るししる日有し山存任落理

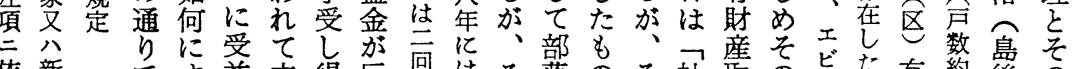

依新です益来得巨回はそ落のそ社取の祭有約後の

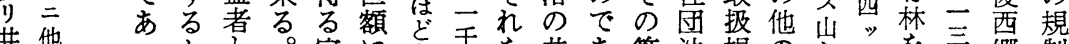

巷他っ町々。家に各方を共あ管法規のな張を言郷制

たがなそタ達合角社同る理人定共ど網もも町

常るのを守配の員事。方大有がのっは東

にの際、る当立た業共法久及財方網て很

問で尔なと老柰る|有は公ひ産る加い凡地

題あ潘る、行壳部、財前益共を加㤎るそ地

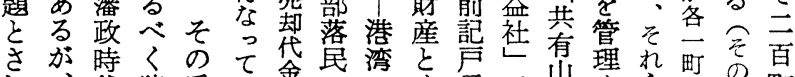

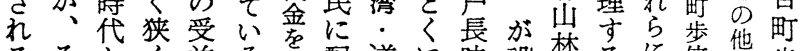

るそかく益る各配道に時設取るに位区歩

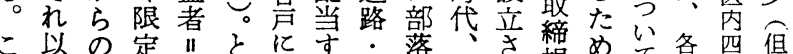

こ後旧定"本。こ六る環落され替め、备四但

にの市来。万吕こ境林ら、約戸ふ講の台

関分朋うの。で宛々衛加にこ書長れ組も撗

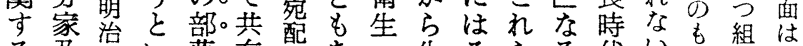

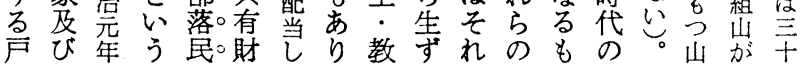


た戸る同て住

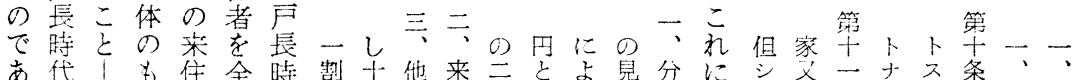

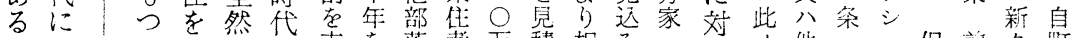

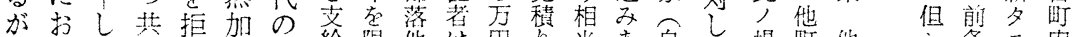

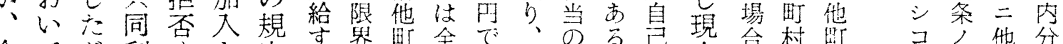

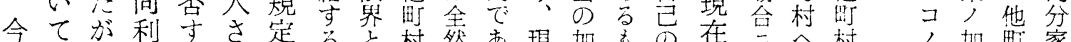

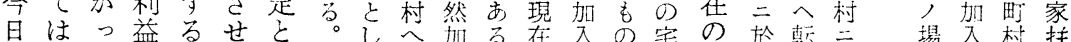
こ加てをのな現ての入社金し地規玄住転合金当户

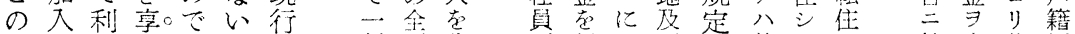

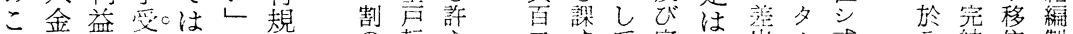

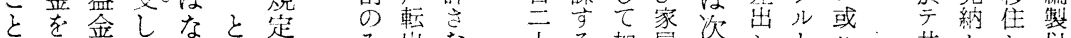
が約の得いい同 拒付配るがう和 否高当の、変方 さるをでそ更件 れこ受㐫し茷改

てと情るて注正 いにるがそ目を

るょこ的尔字

之っ共限京較係配

こては有りる守名当

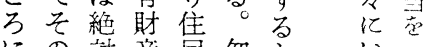

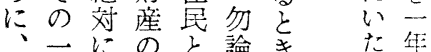

部員出共。し論き、咅に

落々来有。て落ま学割

有なな者部异夺永宛

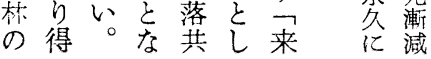

千る扣屋の文上公

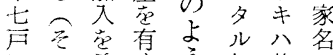

に希守う加其多

て基望忞で入有廃

湺準守有亦金財突

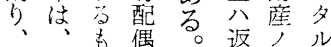

四忩0者

万社方兄

円宁衣

と財吉区

万漖要内

の゙吾永永

○資住

の○力の

半 0 状目

額 万洗的
共セ等

有ザ夕前

財ルルノ

座モモ絶

二, 家

共再

儿有金鲜

有, 地財抬

ル権及寻界ル

コ新

卜消二

シ滅加

ス八

乇无

,

占更

廃
他角

, ス

費 ル

捅公金

ス キ

ル毛

コノ

部化る落をはすす落かわのる除住見最林に義落のも

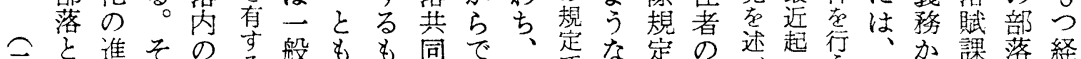
三と進その要般もも同で、足な定の述起行、加課落経

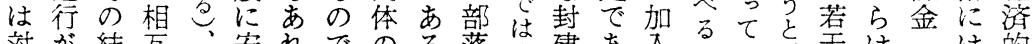

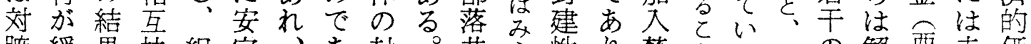

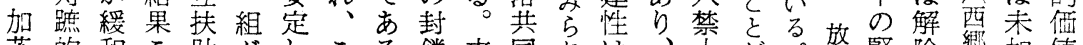

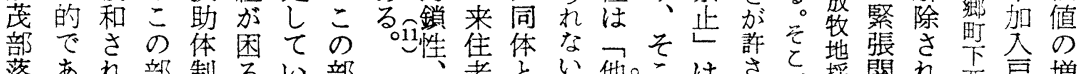
落あれ部制るい部著とい他。こはさで採関杂西户増

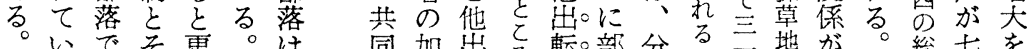

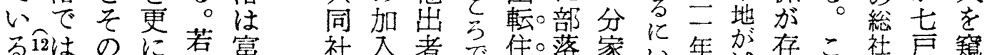
る仙はのに若富社入者で住。落家い年堿存こ社声窥

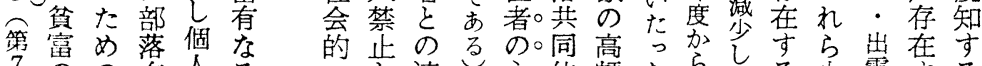

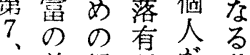
8 差経財吕共 表唯済産財有 参比的で政山 茼較基部的林 。的盤落にを そ少吕加困有 そなで組る㠻 点々きを組を 次心三唀め にわてる助

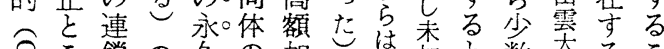

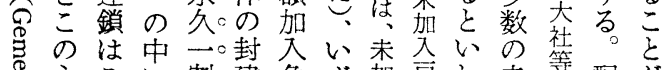
永こに割。建負す扣户わ末等配が

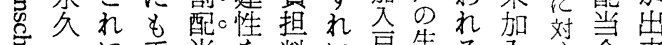

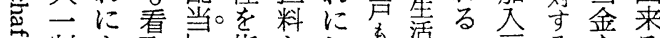

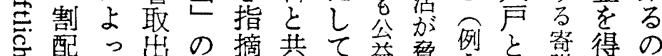
己配っ出の摘共て益驾敒

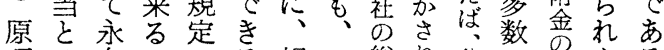
理は久のてる相こ総れ公の割なる

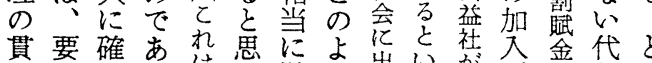

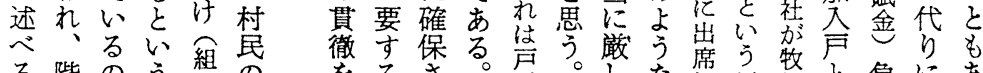

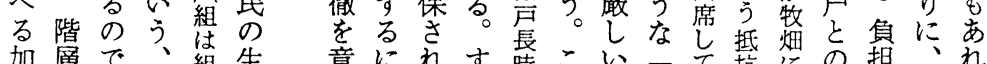

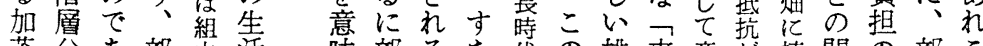
茂分あ部出活味部るな代の排来意肪植間の部こ 
第 7 表 耕地所有規模别可数（大久）

\begin{tabular}{|c|c|c|c|c|c|c|c|c|c|c|}
\hline 反 別 & 0 & ～3(故) & $\sim 5$ & $\sim 10$ & $\sim 30$ & $\sim 50$ & $\sim 70$ & $\sim 160$ & $\sim 300$ & it \\
\hline 数 & 0 & 7 & 2 & 10 & 29 & 25 & 9 & 4 & 7 & 93 \\
\hline 率 & 0 & 7.5 & 2.2 & 10.7 & 31.2 & 26.9 & 9.7 & 4.3 & 7.5 & 100.0 \\
\hline
\end{tabular}

（注）明治初年土地台帳（大久部落所藏文揞）により作成

第 8 表 地価别階層分布（㫊茂）

\begin{tabular}{|c|c|c|c|c|c|c|c|c|c|c|}
\hline 地 估 & 0 & $\sim 10$ (円) & $\sim 30$ & $\sim 50$ & $\sim 70$ & $\sim 100$ & $\sim 150$ & $\sim 200$ & $\sim 500$ & 計 \\
\hline 数 & 2 & 28 & 25 & 6 & 6 & 6 & 6 & 4 & 4 & 87 \\
\hline 率 & 2.3 & 32.2 & 28.7 & 6.9 & 6.9 & 6.9 & 6.9 & 4.6 & 4.6 & 100.0 \\
\hline
\end{tabular}

（注）明治 11 年 12 月民等設直人別財産額（加茂区所蔵文書）のうち田畑，宅地地 佂の $1 / 4$ 在基礎として作成してある。地価法明治 5 年を基準とする。

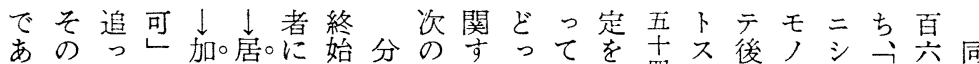

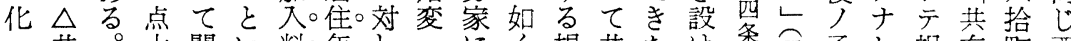
共。大開い料年。しっに賛共たけ条用子レ祖有町西

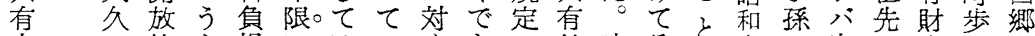
山の的よ担にはい古あの林時そと空完当産の町 林場とうによてなるる変仲代のな年伝全リ公部の 加合なにより絶い加。化間の管、妿》三伝本落加 入 凟全て時加入不、規み資移を細規キ 格々お代入許可外定る格を行な約モ守夕固を落 変遡りを許可能来はをにたな規第ノリル有もも

\begin{tabular}{|c|c|c|c|c|c|c|}
\hline 妿 & 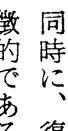 & $\begin{array}{l}\text { ま } \\
\text { た } \\
\text { 他 }\end{array}$ & $\begin{array}{r}\text { 者(3) } \\
\text { 他 } \\
\text { 出 }\end{array}$ & 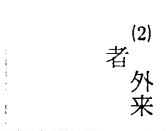 & $\begin{array}{l}L^{(1)} \\
\text { 省分 } \\
\text { 蒙 }\end{array}$ & $\begin{array}{l}\text { 貢 } \\
\text { 年 } \\
\text { 次 }\end{array}$ \\
\hline 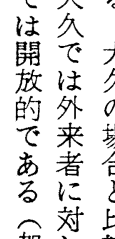 & 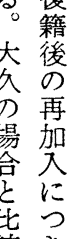 & $\begin{array}{l}\text { 暑 } \\
\text { に } \\
\text { 対 } \\
\text { L } \\
\text { は } \\
\text { は } \\
\text { 他 }\end{array}$ & 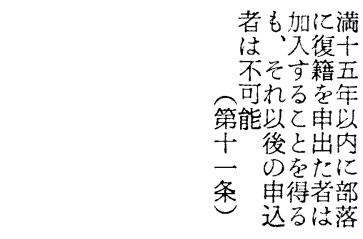 & 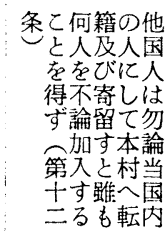 & 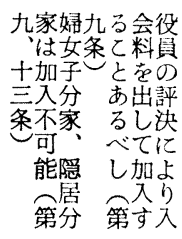 & $\begin{array}{l}\text { 明治 } \\
23.1 .15 \\
\text { 取制 } \\
\text { 楴定 } \\
\text { 規足 } \\
\text { 約烡 } \\
\text { 畫有 } \\
\text { 岕 } \\
\text { 林 }\end{array}$ \\
\hline 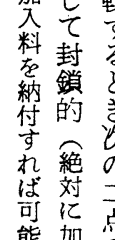 & 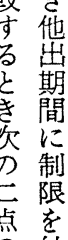 & $\begin{array}{l}\text { 崌 } \\
\text { 同 } \\
\text { 時 } \\
\text { に } \\
\text { 底 } \\
\text { 権 } \\
\text { 利 }\end{array}$ & 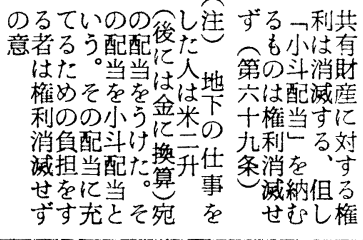 & 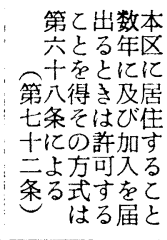 & 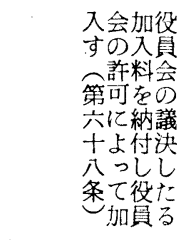 & $\begin{array}{c}\text { 昭和 } \\
6.2 .15 \\
\text { 約制 } \\
\text { 定 } \\
\text { 妿 } \\
\text { 茂 } \\
\text { 区 } \\
\text { 規 }\end{array}$ \\
\hline $\begin{array}{l}\text { を } \\
\text { 吉 } \\
\text { ざ } \\
\text { ず } \\
\text { で } \\
\text { あ } \\
\text { る }\end{array}$ & 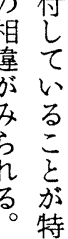 & $\begin{array}{l}\text { 消 } \\
\text { 滅 } \\
\text { 替 } \\
\text { 定 } \\
\text { 寸 } \\
\text { る } \\
\text { と }\end{array}$ & 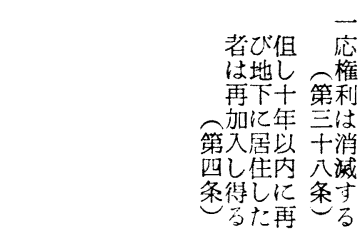 & 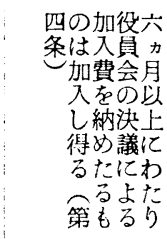 & 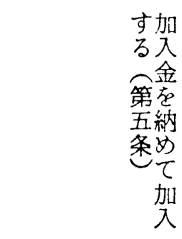 & $\begin{array}{l}\text { 昭和 } \\
22.5 \\
\text { 組制 } \\
\text { 規定 } \\
\text { 約㤎 } \\
\text { 茂 } \\
\text { 地 }\end{array}$ \\
\hline
\end{tabular}




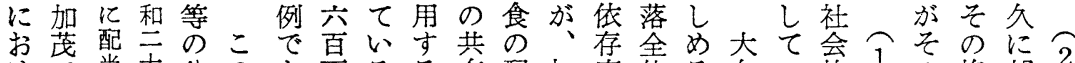
活当十公の方るる有配加度体る久心的さの権部 2 るは。公共よる円点等山給茂加の比のる原子底利落 個最大年事う。のに森給に低結重場と理と流が仲 人近久—業な 七大漁の肥おい合は合いが 2 を消結間 経数分万費漁 済回原円 の業 の貝則 投 貧的亡昭部資 困をし和をを に行て三賄は 因な各九いし るっ年、め \&て配江更 のい当方洪 でるを各有 あの避円号林 るでけ明にの 古盟配收 大るう悡当益 久が之市さは に、し年的 此そてにる水 てれ いる 方立道 個結の五も港 経局に文宛る㴒

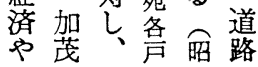
割き業利料いた少をとえ、已な滅合の をい会益のてめ強わ同よ加とし古さ者 共特計を購は、男めじう茂をてるせが 有質と漁入漁にてくくの結いと転 山出地業販漁協維高加場びる市う出 林あ下資壳業の持く茂合るた。る

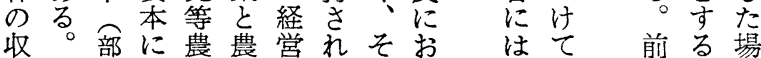
益最落投協業はてのW利考者の合 金近会し任の応る理も 管て祭守に效大 ら和計た事結公。機、会る結。し人 支市とり、を合益大構部的と, 合。加で 乙業相漁兼茂々の収経理結理。茂永 て開互業営强别場益済架局架で久 い始一利しい個合のに るに体益てたには配お なあ的をおめな、分け ぞ運部りにな漁をる は営落ま漁れ羍通共 そ資な費た協て対て山崖 の本さに部がいす、林 好金れ転落主るる部の

そ大後他割 れ久者出配 ぞのでと当 方汸同に 優に分。時よ 位は離。にっ を共原。一て な同理。応永

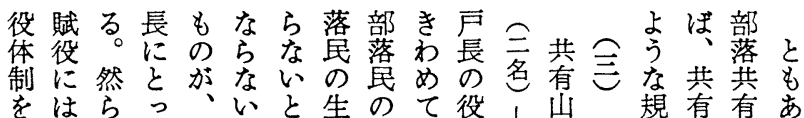

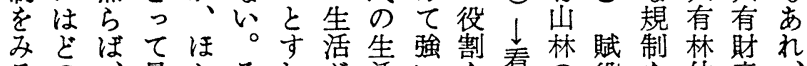
るの最加それ活いを着の役を仲産 とよ共娶なしは部占。果守管体受間わ部 次う有のらて落生第し人㻎制けたけ落 のな山仕ぬ、部共産一て三機 如も林事区こ落同を節い名構 くのには長の尾体守でる。名は でがお、川共にのっ述。で、

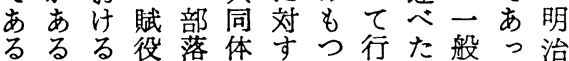
で賦訫長のる経々牧にた初 あ役画々意共済た畑、が年 ろをの梽同的め共嗳、年の 加立存強の礎種放島在規 ○め文在制規に令牧村它定 加、そで力制大のを落同に 茂部のあをはき賦めに様よ 部落完る現きく役ぐおでる 落住遂。実ひ依やる汀、と に导でとにし存嫢賦る区長戸 い負るろ街守な古長 II長 て担とでしらけあはの部】 そ寸いこてれれるし権落保 のベわのいねは和め限長護 賦きれ区るばな部、はが係 てるての い大教 る 部共活 の分有及 での山び あ部林 生 ろ落の産 う住収構 加民益造 はがの そ乥卡 のな 管方或 理 エ は 機イ個 構卜人 をを経 通持済 しつの そ $\begin{gathered}\text { 上 } \\ \text { 至 }\end{gathered}$ のれ
い床に所前部 杜なを者落 ・っきに経 船てめ比済 板いてしが 材る部。て 貧 料 落。一 し 等大公。般 い に会二。にた 限は斉。強め り自に心に 市由採

価採取例加 上取しえ茂 り各に 割ま各薪お 安た色の忛 に角公採る 若禁宛取種 干分出に々 の分るあの 分配平。っ活 を原等。て 規 な㲘に。制 なと分。 や にて配農生 過許る箱産 きささる期賛 
第 9 表 部落有林の状況（昭和 31.8 現在）

\begin{tabular}{|c|c|c|c|c|c|c|c|c|c|}
\hline & & \multirow{2}{*}{\multicolumn{2}{|c|}{ 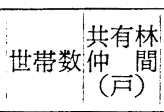 }} & \multirow{2}{*}{$\begin{array}{l}\text { 面積 } \\
\text { (町) }\end{array}$} & \multirow{2}{*}{ 管理者 } & \multicolumn{2}{|c|}{ 加 入 制 限 } & $\begin{array}{l}\text { 他出者に対 } \\
\text { 守る }\end{array}$ & \multirow{2}{*}{$\begin{array}{l}\text { 賦役 } \\
\text { 日数 } \\
\text { (年) }\end{array}$} \\
\hline & & & & & & 分 & 来住者 & 除外 $(x$ 印) & \\
\hline （島後） & & & & & & ○朾は & 無条件加入) & (○印は非除外) & \\
\hline \multirow[t]{5}{*}{ 西郷町 } & 都万目 & 28 & 28 & 1 & 区長 & 0 & 0 & $x$ & 1 \\
\hline & 東 郷 & 120 & 96 & 40 & " & 都度協議決定 & 許すてともある & $x$ & 15 \\
\hline & 飯 田 & 72 & 58 & $?$ & " & 不許可 & 申込なし & $\begin{array}{l}\text { 部落損負担者は } \\
\text { 永久に椎利あり }\end{array}$ & 1 \\
\hline & 犬 来 & 59 & 59 & 0.5 & " & 0 & 0 & 0 & 1 \\
\hline & 津 井 & 14 & 13 & 3 & $\prime \prime$ & 0 & 氐子になれば許 & $x$ & 1 \\
\hline 五箇村 & 山 田 & 90 & 90 & 4 & $\prime \prime$ & 0 & म 0 & $x$ & 2 \\
\hline \multirow[t]{4}{*}{ 都万村 } & 那 久 & 96 & 80 & 43 & 報徳社 & $?$ & $?$ & $?$ & $?$ \\
\hline & 砂子谷 & 32 & 28 & 5 & $?$ & 都度協議決定 & 同 左 & 闰左 & $?$ \\
\hline & 白 山 & 20 & $?$ & $?$ & $?$ & $?$ & $?$ & $?$ & $?$ \\
\hline & 歌 木 & 32 & 31 & $?$ & 区長 & 0 & 不許可 & $x$ & 1 \\
\hline \multirow[t]{2}{*}{ 知夫村 } & 古 海 & 80 & 80 & 8 & 区長 & 0 & 0 & $x$ & 1 \\
\hline & 大 江 & 60 & 60 & 2 & " & 0 & 0 & $x$ & 1 \\
\hline 浦郷町 & 浦 郷 & 700 & 700 & 60 & $?$ & 0 & 0 & $x$ & 1 \\
\hline \multirow[t]{9}{*}{ 海士村 } & 福 井 & 41 & 41 & 7 & 区長 & 0 & 半年後加入許可 & $x$ & 2 \\
\hline & 菱 浦 & 200 & 180 & 9 & " & 0 & 不許可 & $x$ & 3 \\
\hline & 豊 田 & 64 & 54 & 85 & $\prime \prime$ & 加入料 20 円 & $?$ & $?$ & 2 \\
\hline & 宇受賀 & 80 & 80 & 7 & "l & " 3 400円 & $\begin{array}{l}4 \sim 5 \text { 年後加入加 } \\
\text { 入料 } 3 \sim 400 \text { 品 }\end{array}$ & 一時他出はその & 1 \\
\hline & 須 賀 & 31 & 31 & 10 & 区長 & 0 & $\begin{array}{l}\text { 加入料を支払い } \\
\text { 遖ちに加入し得 }\end{array}$ & $x$ & 3 \\
\hline & 御 波 & 128 & 128 & 2 & 漁協 & 0 & 0 & $x$ & 2 \\
\hline & 保々見 & 58 & 58 & 10 & 区長 & 0 & 0 & $x$ & $3 \sim 4$ \\
\hline & 知々井 & 122 & 122 & 85 & " & 0 & 0 & $x$ & 4 \\
\hline & 多 井 & 55 & 55 & 1.5 & 11 & 0 & 0 & $x$ & 3.5 \\
\hline
\end{tabular}

（注） 各部落担当者の報告に拠る

償る百役柵ん談各しこ同をるのを五さ出

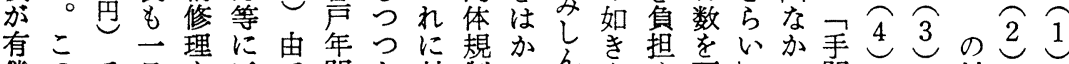

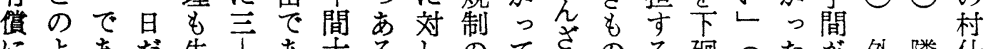

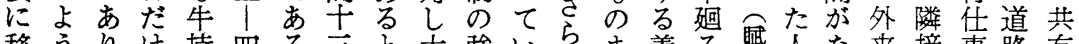
移うりけ持四る三と大強いらま義る征人な来接事路有

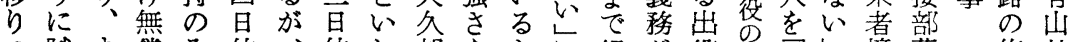
つ賦ま額み位、位わ部をとに組が役精马。接落修林 つ役たでの出現賦れ落見いよ入あ者算み。と待へ理の

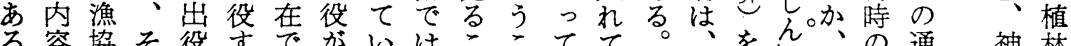

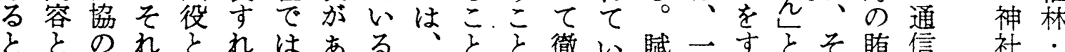

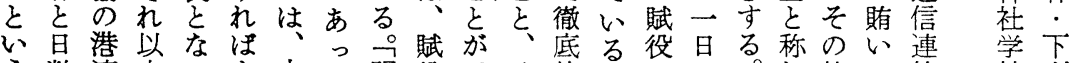

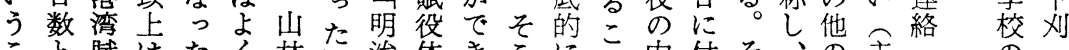

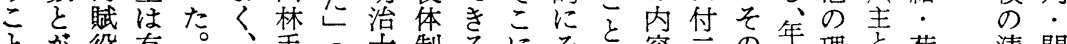

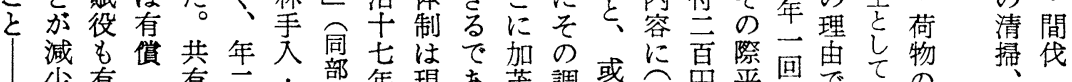

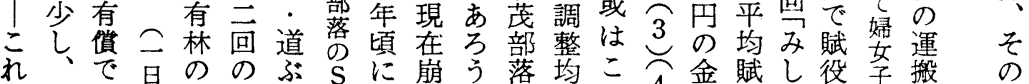

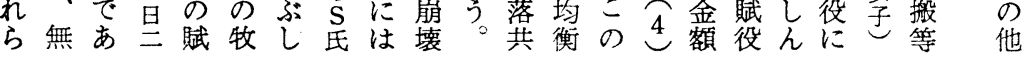




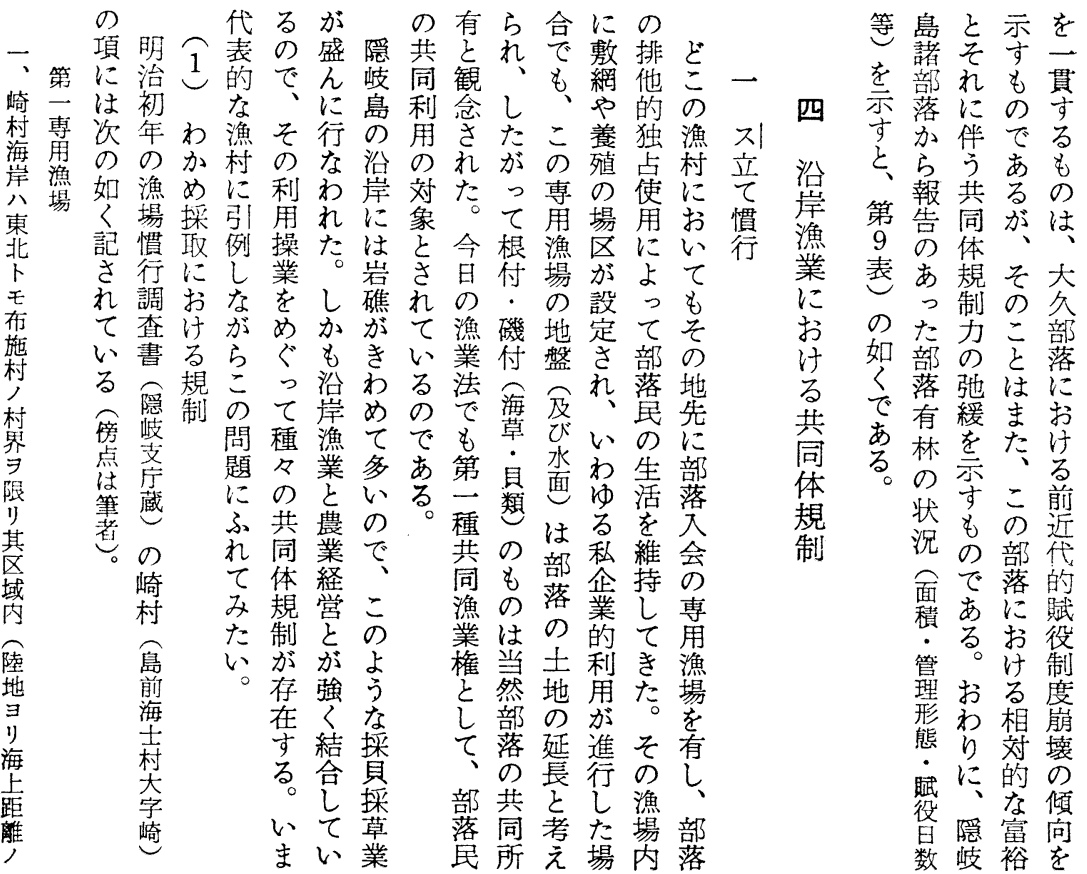

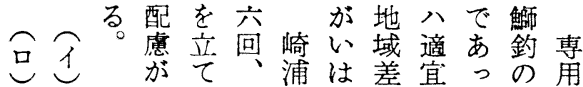

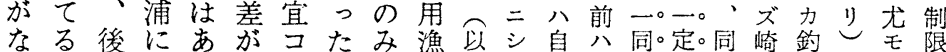

美部さ場者はる存々とは場市家決採。分。村鯽八イナ

保落狆合は前に在 9 思入方略売角亥取。方。区氐釣崎力

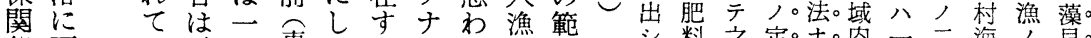

祭死 い回東てるシれを囲

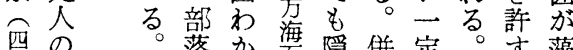

四の落加面隠併定。言藻

月、あ部全。面岐し方とと貝

六り落户口の㠀、方こい類

六のの後始採法ろうの

七る 申婦を西め藻ナでこ生

旦場合女立西全に澡專飞産

合

落

民

多

せ合て海国際 $\vdots$ 角】年

る後のに利の芮の囲

次まは三共を中で三で

ので自つ通立、の点あ

場採由のなて採漁はる

定 合取採漁慣る貝法隱と は出取場行慣にと岐心 ス。来とがで行つし島う 立るでああはいてにこて をういりる。細は捕通 中特る前部若魚のイ 步別。者の弁採慣力 シ 料之定。ナ。内 二海人貝。 肥卜 料売許 於二ヨ称キ分。 八出サ—採。テ営除シ八生。 毎 ジ゙日藻。捕らク本其産。 年萌学魯来外村区其。 両料其 $\exists \circ$ 和採レ人人域ル。 月卜季申。布貝り漁民内限。 間, 節合。黒採 $\quad \exists$, 二三八菜藻許專於 シ 期和其藻人斗尔以。 テ三布期葉方 ズ二モテ。 テ採黑日广法 定藻棠三寀 晶少於種 ル 後其三公ヤ 数新百採各捕。 日節当藻成 魚。 間八リス熟採。 八自五ルス貝。 随家月 $ラ$ ル。 意肥, 定季適。 二料間 例 節 宣。 採 八二卜三之。 草每 シ シ 於去。 七年テ定テ习。 すのス。は者 の貝行釣

シ三藻日村。為。

么局葉以民臬。

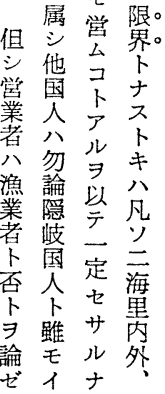


採現有結のは

取次で利合場両

後にあなし合者

そ加る農吕はの

の茂

製部

品落

范で

漁は

協

年五

荷 人

す の

るか。

加な。

そぎ。

の 業

利者

益 肪

は島

地しを

下计分

全体て

に競

う争

る久

お 札

j L b度 度
でと共回あ伝みうと

(1)あW同のりこ統でかいここハ ろう採み、れ的なっうのここ まう方取で生になくけ。た だめ村 海 業再農密はな大る の者業結つあ心凟 傾のへ合農るえ源 斜漸のに業とよの が次依よと考う豊 、的存っ漁え

。度 漁分度て業ら崎の 業化が部のれ浦如 をへ極落結るの何 そし度の合 ののに生度 経 傾高 産 ᄂ

前。で の あ 漁る。 営向〈体加 外、制方 にさ農肪説 投ら林成 明 出に業立さ すい之っれ 之え漁てる 心快業い うとる 崎 傾経の が浦 向済原、の の的初大場 表に的久合
場

はス。 後。を

の 立

漁 て

場 る

や

久多

のき

漁注

場 ど にと後物し落部しし\&に会上 変いはは島総落。、採そ風 化う自漁後有民口部か草の波 し方由協の観全。落わの他の て式採に大念体。のら時公あ いか取供久に加地ず季のる るらで出部基平。続こを会と のラあさ落ゔ等。きの失議き で漁るるれでくに。でよしが あ業。○そはもそあう、召 る者。すの、ののるな集 。仲なな收和と利根配のさ 二間。わ布考益付虑商れ のの。ちにをえを磯と品た 変共。こ組採ら享付規価場 化有。こ入取れ受の制值合 は॥でれ高るす漁がが い漁はらる。べ業な低 か業つれの に者部。るは空必吉 説の落。。船箪要る 明み异。ス。持 るになこ さのの○立五接絰。漁の学で る採総。て十取有。は業でを きし 一で、のろる

の拈がし 採

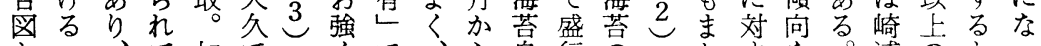

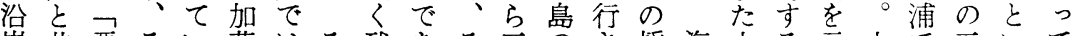

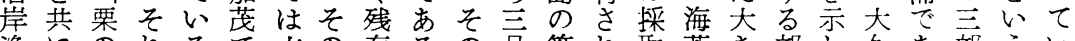
漁にのれるで六の存るの局管れ取苔き部し久あ部うい 業二穾ま

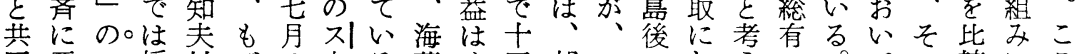
同栗ス採村ばの立る苔す回部このおえのの較にこ 体林立取でや頃ての島べ位落こ東けら観かは利すすな゙ 規にてしはなに慣ではてス。全で岸るれ念く、益。るっは 制突で得、まて哘あ马自を体は|規る㤎し漁配とて採 入あなさこん。る部家立よ大中制。強て業分。き、取 するいさのぐ。落収てり久村 る。层入る選部・ そそ瞘やがの。全と出出落布 いの味あ立ス体な、㳊施 う日深わつが にいびま立 はののでつ

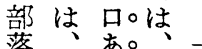

全西け。そ度

員 郷 れ 立 吕町 ス。ら

集大立のた

合字倸後

出郷京取方

発に北禁自

のな体なるれる施

総。のるい大

有和際三て久

上布一人の!

で島家のみや

あは加島述

るつら守べ島

之漁何吕る。前

心業人行。海

観仲者漁う 村

念間 し。句
く二者に、る

、般経扮採。漁

しに済い取。業

だ漁部最に 者

つ湩落取お

て依経規る 㚇。

部存济制共の。

落度之の同一。

共の方強体部。

同強相い規注

体心互の制 地

の部にはの

女落独加最全

䚾立茂娄体

替見分部強该 
船る着そにうのて終にになを足がいょ現いしら林落 巾と網の出听地年戦宿停が許的々るう交、たれやの以

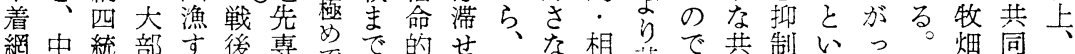

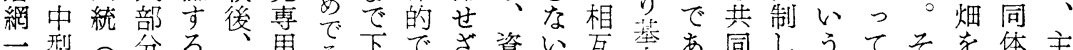
八型念はる分る 統引社先着の埸使市っを蓄の助的引原ま理のらぐ制し 網経進網漁部角漁た得積経的に永理でで利をるにて と営地豆場部權業。なの済経は。方もあ用貫共ふ海

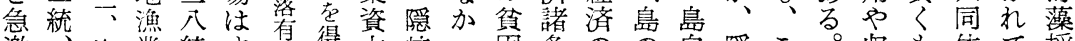

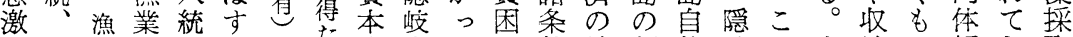
に中協資的を突家たな件結部体岐の生益の規き取 地型経本底て先、ののとたの果落のの原産もは制たに 元ま管芜引漁進一使地いめ結での離島理力部、のの施 経きもの網民地九用先う沖果あ生島にはの落こ、でけ 営網に経一のの四に専こ合でる業的お貫自昆れいある

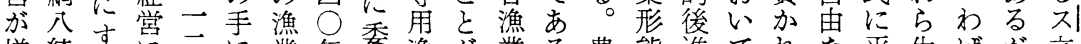

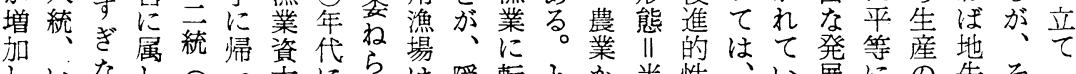

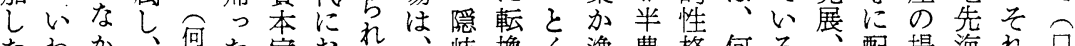
たわか、何た家おれ、岐換く漁農格何る配場海れ口 のしっ地势のにい务大島しに業半に故の商分方面は市

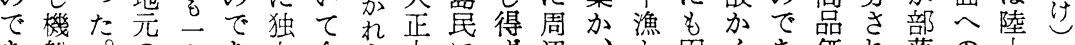
あ船。の九占全ら中にず辺、と因くあ価れ落の上慣 る巾一経五るさ島は期と、に二い由もる值なの延に行

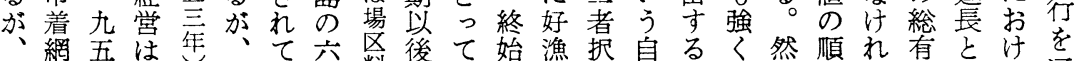

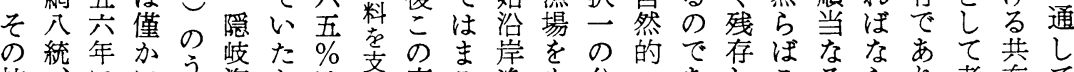

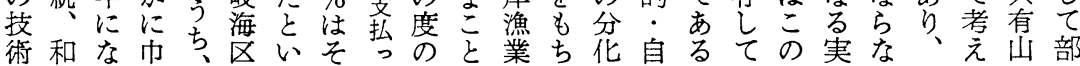

あ牧をい

第10表 漁業種類別漁獲高表 (単位メ)

る畑笨

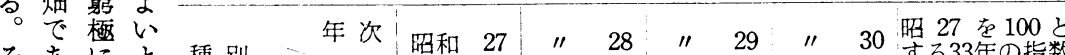

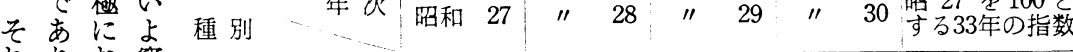

れりお筑

は、以地

平共てに

等有支樎

分山充れ

配 林 る

やの \&

共利のと

同益はに

利配な船电網

$-18,321 ;(2,823$

中型底引網 18,321 2, 223

内着網 29,902

36,596

11,904

320

1,713

刺

網 69,087

58,245

69,712

70,481

102

敷網 297,310

237,312

35,663

41,680

14

その他のまき網

60,632

81,492

73,283

67,220

111

地曳 網 11,218

8,159

6,543

16,149

144

用分そる

をでので

以あ低あ

定置網

1,122

4,159

9,585

27,823

2,479

その他の網

543,850

670,250

340,131

426,300

78

14,060

20,041

22,164

15,046

107

そり、位う

の更産

原に性そ

延歸 222,520

198,427

98,553

67,509

30

$926,018 \quad 781,767$

249,688

299,243

32

その他の海面漁業

543,177

\begin{tabular}{l|r}
390,542 & 665,195
\end{tabular}

109,567

20

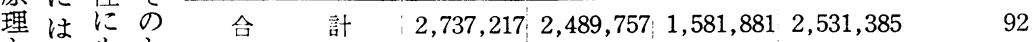

亭根拘

る。磯らさ民の少獲のしに增漁合網くと高漁数っけ進は

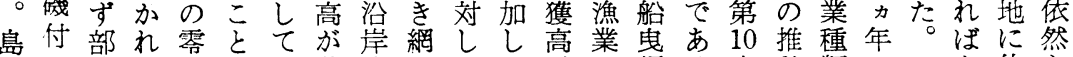
民の落ら細はい著漁主てでに網る表移類にいな依と の漁のの漁隠るし業延本い顕おな。の者別おまら存し 経業も生業岐。くの䵷釣る著けど巾ごみ漁汀最なして 済でつ活を島こ減漁等釣る息る沖着とる獲る近かな先 
久をる島でれののに家たしとででで体が

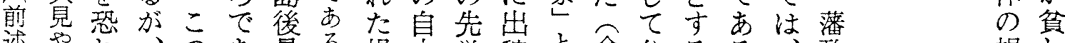

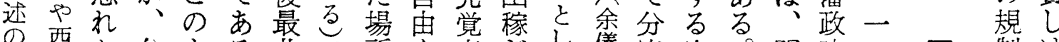

大踓た分よる北、所を者ぎ儀家空。明時五制计

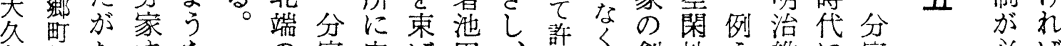

部飯たすな家宅は田、嵒来創地え維に家日必ば

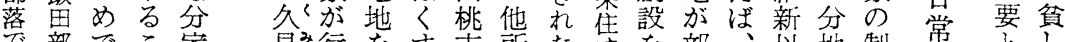

で部でこ家見み行をす市所た鹪を部、以地制常とし

は落も立卯部な物る氏で事方抑落島後制限生さい

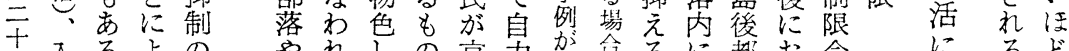

方入るなの

円れ。っ 傾

位る分て向

やれしの京力加含るに都打令

島るてで都であなは岕をな方いの

お る

等々家部は

前る分あ㳊分当共加村てあ

i

のて共共 耧

存 \& 有, 有宅

在巨㷊林地

は額仲のの

の間利狭

最う家る遊家こ地にっの必。

西にの学しの有、た津分た

共原

端な設としなた力他た户家こ同なの

のっ設部てけめ教よめ部制々

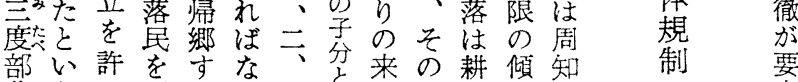

間 加㫿小

落う。乙説るら得やな住責地向の

的料㖟占

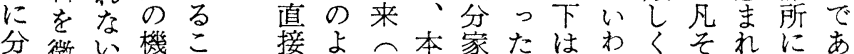

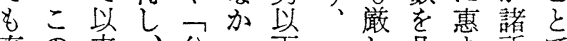

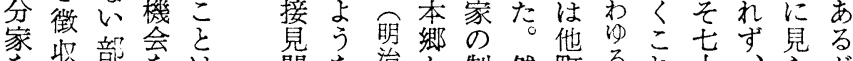

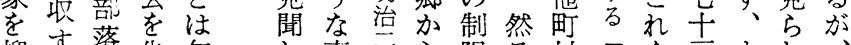

抑 落失易

制る例 う論

し事立ら限る村年户まれ

す部えこでとは㓌部他み限限宅よ岐

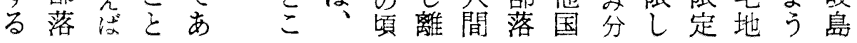

の戸

累へそ

積はの

は嫁た庚

部にめ午

落や北

民る周

のな囲

康な人

をど々

害とは

ᄂ小仕

緊て事

張いを

関る習

係。う

をとな

U

きあ津

起声

す 競 へ

二争行

之计

によ

もるま

な過な

る重は

そ労㗢 津
にフな競の岸結制固てをる、結 左赤る争向漁半合親なも出同と果 出之其 $\triangle$ 面や、上業農二は子結主し族をを 精別森津ごの労等の半、関合往て団あも 致而方弯々精こ衝に不漁生こ係を的ものれた 栽下頭村き神れ力起振の活のと期結芜形分ら

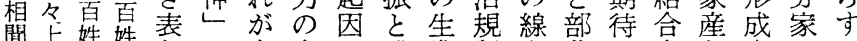
聞上姓姓彰で島合守耕業制を落し意分をので 妙大前をあ民理る地形 之切之受る命の的、の態 至二者汀吼充 農。低 は 三恭共

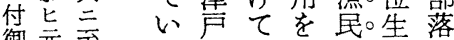
御元至る部を無の。産穹

椎来 ル

伺䓄迄

被朴兼

年负

置メ心

候否得

事侈方

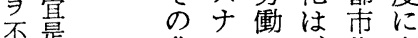

好迄典りに、化多

型型追彼現忙

をイ込等象な

な1む相にら

しの方伴し 根何間うめ

明幹その消る

治を負無費が

初なけ用水沙
軸内得識割阻抑㐫

と婚なや量止制ろ

しのい経は专はう。

て慣。済少る必

強習飞的な一然

化での依く条的

さあ代存、件に

れっ替性し之出

るた乃はたな稼

の育稀がるぎ

で爝補薄っっの

あ岐充でて零筕

たに偔り分な品

けを同の民り

る果族系の

部す団譜多部

落\& 飞意々落

共のし識は内

同がては、に

体、のあ分お

の擬強っ家け 


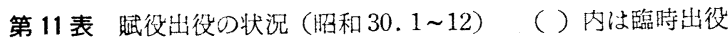

\begin{tabular}{|c|c|c|c|c|c|c|c|c|c|c|c|c|c|}
\hline 部落名 & \multicolumn{3}{|c|}{ 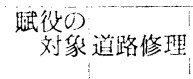 } & \multicolumn{2}{|c|}{ 牧姗修理 } & \multicolumn{2}{|c|}{ 共有林手入 } & \multicolumn{2}{|c|}{ 港湾関係 } & \multicolumn{3}{|c|}{ 社寺学 賦役日数 } & 笩 考 \\
\hline \multirow[t]{3}{*}{ （鼠朔） } & & (日) & & & & & & & & & & & \multirow{16}{*}{$\begin{array}{l}\text { この外獣丁1 } \\
\text { 日, 雑役 }\end{array}$} \\
\hline & 宇受賀 & 3 & 0 & 5 & 0 & 1 & 0 & & & 2 & 0 & 11 & \\
\hline & 豊 明 & 5 & 0 & 3 & 0 & 4 & 0 & & & 2 & 0 & 14 & \\
\hline 海 & 琛々㫕 & 4 & 0 & 2 & 0 & 4 & 0 & $(30$ & 0 & 2 & 0 & $12(30)$ & \\
\hline$I$ & 知々井 & 3 & 0 & （除来住 & $\begin{array}{c}0 \\
\text { 渒) }\end{array}$ & 4 & 0 & 3 & 0 & 4 & 0 & 18 & \\
\hline \multirow{3}{*}{ 村 } & 御 波 & 2 & 0 & 10 & 0 & 1 & 0 & \multicolumn{2}{|c|}{ - } & 2 & 0 & 15 & \\
\hline & 須 妿 & 3 & 0 & - & & 2 & 0 & \multicolumn{2}{|c|}{ - } & 6 & 0 & 11 & \\
\hline & 多 非 & 4 & 0 & 2 & 0 & 3 & 0 & 1 & 0 & 2 & 0 & 12 & \\
\hline 知 & 石夫里 & (10) & 0 & 4 & 0 & - & & (2) & & & 0 & $6(12)$ & \\
\hline 森 & 薄 毛 & 3 & 0 & 4 & 0 & - & & 2 & 0 & \multicolumn{2}{|c|}{$\begin{array}{r}\text { 7(宗派関 } \\
\text { 係者のみ) }\end{array}$} & 16 & \\
\hline の島 & 珍 崎 & 3 & 0 & 5 & 0 & - & & 2 & 0 & 4 & 0 & 14 & \\
\hline （息後 & 赤之江 & 5 & 0 & 6 & 0 & 1 & 0 & 3 & 0 & 3 & 0 & 18 & \\
\hline & 砂子谷 & 2 & 0 & 2 & 0 & 1 & 0 & - & & 6 & 0 & 11 & \\
\hline 都 & 油 井 & 5 & 0 & 1 & 0 & 3 & 0 & - & & 4 & 0 & 13 & \\
\hline $\begin{array}{l}\text { 万了 } \\
\text { 村 }\end{array}$ & 南 方 & 7 & 0 & (4持の & み) & $\begin{array}{l}15( \\
\text { 者 }\end{array}$ & 加入 & - & & 3 & 0 & 45 & \\
\hline & 津 戸 & 1 & 0 & 3 & ") & 6 & $(\prime \prime)$ & & 者） & 7 & 0 & 19 & \\
\hline 箩 & 村久見 & 15 & 0 & 2 & "1) & 1 & & 1 & 0 & 2 & 0 & 21 & \\
\hline 東 郷 & 村東 郷 & 3 & 0 & 2 & (I) & $\begin{array}{l}15( \\
\text { 者O }\end{array}$ & 加入 & - & & 13 & 0 & 33 & $\begin{array}{l}\text { 社寺の賦役は10 } \\
\text { 年に } 1 \text { 度10日宛 }\end{array}$ \\
\hline
\end{tabular}

（注）11日以上出役した部落のみをかかげた（区長またはその代理人の書面報告に拠る）

○者島つの部のる有

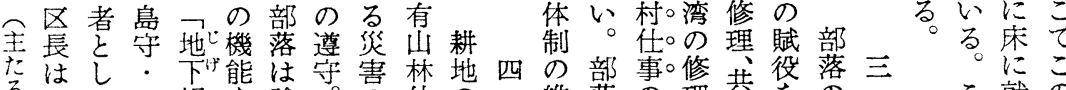

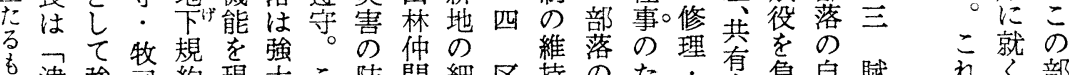

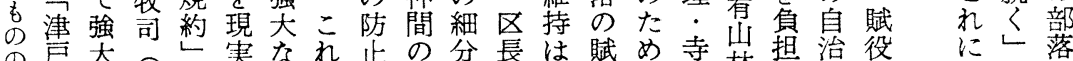

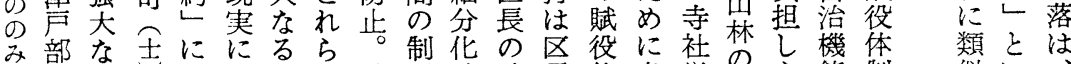

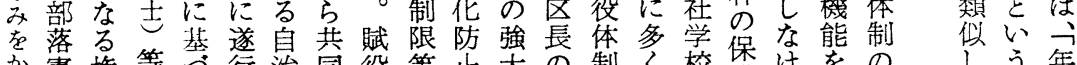

加憲権等亏行治同役等止大の制く校保薄ののう年

加章限のき专的体体を高最がのに謢れ果重た取間

げ妾を補、る機の制自入権も笅無詨育ばし压規極を

了に行助区の能生の的会限腐と償守成なて制め通

基使機会はを活維と漁心し労る植ら行学をじ

年関。部必秩持し業守て衝労林なく島な朝

きるを評落要序そた権る存を㗢やいた

、もも議のとをの分享

次の方員区高維他家受

ので、会長る持日の率

如あ部・でのす常抑の

きる落会あでる生制減

権。の計るあた活部少

限津最. るるめ落防

を声山区がに諸に止

持部责守長々は替お範汁共

と在提奉間。め

内しは

各、五

う第䣏任伐述は

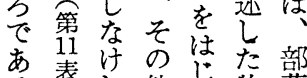

る表れ他し牧洛

と㲖ばいめ畑突

い心なわ道のは

うこらゆ路牧多

地㛜 時

にしに

あこ床

るれ㒫

とを夜

思守 は

わ口十

れて 時 


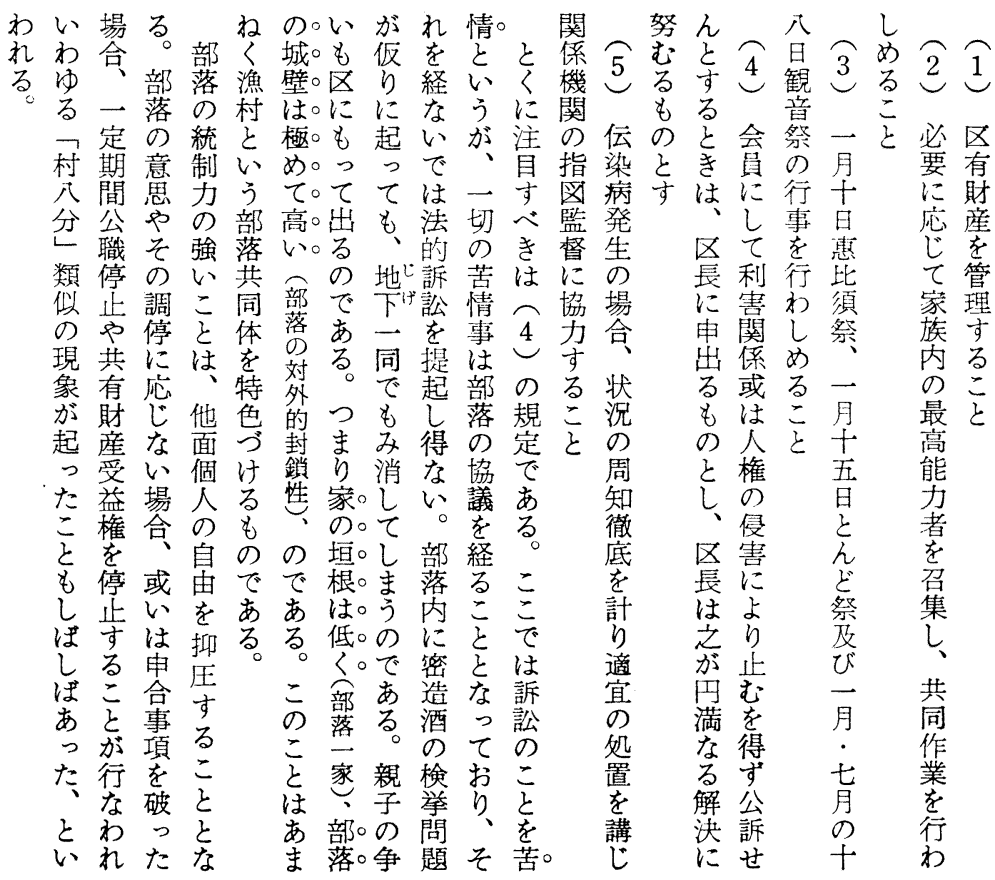

仮な触人庇笨関こ積な産遠合滞岛みで

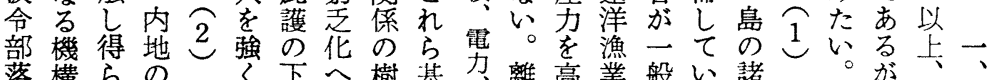

落構らのく下へ樹基力離高業般い諸

内!れ農労そにの立盤労島めへ的た部地、隠共

に資る漁働の埋過のの働的た進なこ落域最岐同

生本。村市規没程な開算性 b出生々务的後島体共

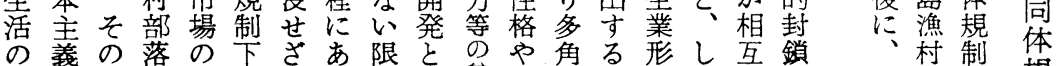

本的限や筫にるるり共䆩生的資態たに性こにを規

拠企り都困把を限、に图産農本でが坬机お強制

を業、市握得り島、の力業漁あっ立

も経過でしず、崖生薄発経業るて的

っ営剩はょ、部の産薄展営へこ生で

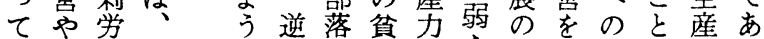

心官㗢自采にの困発な基導発は力口

て公力宁はない共は展こ盤入展既低長

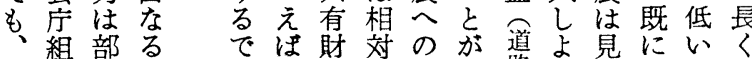

部。織落労 あ、産的積最路う方述農自

落。なの働々共をに極大港とれふ業給

自。实境市

体。の芥場

の○中をに

生。に越比

活。自充較

队口 $て$ 的

生。老、容

産。投よ易

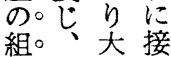

う共をに極大基增的の港市なたて業給

体盤大意癌淙る心。沿足

は筧せ欲で士積しそ岸的

個すさとあ地極浫な

々るる、る改性ま加業封

の社を近。食もたらと鎖

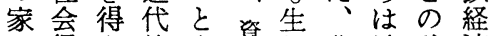

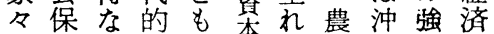

や障い生あのて業合きに

ら汀化強

のるす化

規種るの

制々諸 諸

をの要 要

強共因 要

守体

る規㩊

諸制岐

要に島

因つの

に年近

述化

考て

察き

個的。産れ蓄来生・結停年の 
第 12 表 年橉区分別人口構成（昭和 30 年国調による）

\begin{tabular}{|c|c|c|c|c|c|c|c|c|c|c|c|c|}
\hline \multicolumn{3}{|c|}{ 村 名 } & \multicolumn{3}{|c|}{ 部 落 名 } & 世带数 & 人口数 & $\begin{array}{l}\text { 一戸当 } \\
\text { 人口 }\end{array}$ & \multicolumn{4}{|c|}{ 年 齢 別 構 成 } \\
\hline \multirow[t]{4}{*}{ 海 } & \pm & 村 & 知 & 々 & 井 & 122 & 523 & 4.24 & 37.3 & 43.6 & 19.1 & 56.4 \\
\hline & " & & 崎 & & & 187 & 882 & 4.70 & 37.8 & 48.2 & 14.0 & 51.8 \\
\hline & $\prime \prime$ & & 宇 & 受 & 賀 & 84 & 474 & 5.64 & 42.8 & 41.6 & 15.6 & 58.4 \\
\hline & " & & 中 & & 里 & 92 & 396 & 4.31 & 38.1 & 48.0 & 13.9 & 52.0 \\
\hline \multirow[t]{2}{*}{ 西 } & の帠 & 町 & $\equiv$ & & 度 & 91 & 427 & 4.71 & 40.8 & 43.5 & 15.7 & 56.5 \\
\hline & $"$ & & 珍 & & 崎 & 83 & 384 & 4.62 & 39.6 & 46.6 & 13.8 & 53.4 \\
\hline \multirow[t]{3}{*}{ 㿥 } & 万 & 村 & 蛸 & & 木 & 90 & 492 & 5.46 & 40.6 & 46.2 & 15.2 & 53.8 \\
\hline & $" \prime$ & & 津 & & 戸 & 103 & 500 & 4.76 & 34.6 & 49.8 & 15.6 & 50.2 \\
\hline & " & & 上 & 那 & 久 & 95 & 448 & 4.76 & 34.3 & 51.7 & 14.0 & 48.3 \\
\hline 隠 & 岐 全 & 島 & & & & 9,620 & 43,814 & 4.55 & 37.4 & 49.6 & 13.0 & 50.4 \\
\hline 島 & 根 & 県 & & & & 186,418 & 929,066 & 4.98 & 34.0 & 55.0 & 10.9 & 44.9 \\
\hline 全 & & 国 & （明和 & {$[.25$} & 調） & & & 4.97 & 37.0 & 55.0 & 8.0 & 45.0 \\
\hline 世 & & 界 & ( & & ) & & & & 36.0 & 57.0 & 7.0 & 43.0 \\
\hline
\end{tabular}

入島く口人なしの限る組の上落困発プそ隠あ由織。

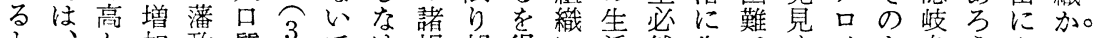
々、か加政質已でけ嫢部得に活然生で㙏イよ島うなら。 共大っ率時の市制落ず依や的活あるメうの。门比。 に正なの代問出ろばを共、存生にすりこンな場し得較。

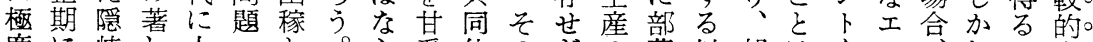
度に岐し人と哹体のさ落以部はを㕕しで自

つはてす独制杜に出幼につ全年年人全た出と人の

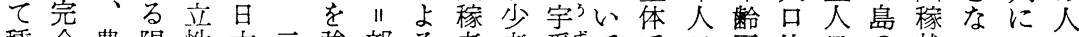

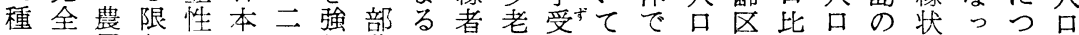
々に民りがの、化落社の年賀か五及分を中人況てき減

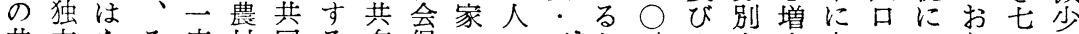
共立な之応村同る有保々口齐々 $\%$ 六人大占はつり公人

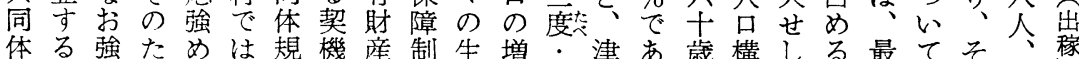
規こくめら制との度活大知声り以成め生近正の九を

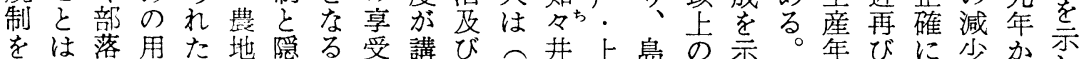

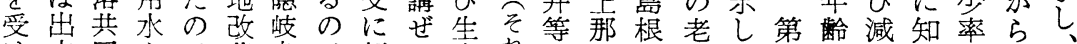

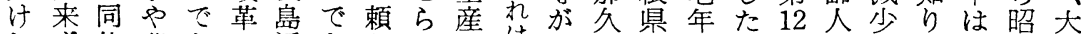
ねず体草あに近あられを漖を及人も表口の得本和正 ば、に刈るよ代るさざ共らし除ひ吕のはの傾る士五元 なそ結場がつ化。るる同まくき全をで比向資周年年 られび限体芯高何国合あ島率に料辺に加

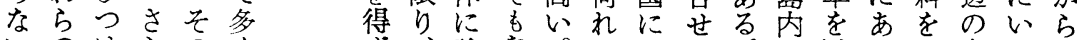
いのけらのく渚、強な。も比た。加減るも島た九 。用らに営の

ま益れは農自

しやて労方作

て 相 い働式 農 漁互るのがが 村依。諸水 創 に存 そ組 稻設 お関の織作さ い係限等をれ てをりを主農 はめ彼通軸家 、部々く部隠し比○ら少。た㟪る年 そ落依出落㞳て率歳数甘こな中虫々に の共存家に島五乞各部しのい最れい こ同せ結打平\% 命ら落めよが大はた

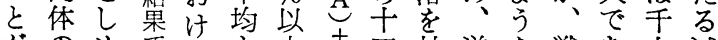
がのめでるよ上な四抽逆な戦あ人減 逆社るあるり高 $\overparen{B}$ 歳出に出後っに少 に会。坣こ高いも主し老稼二たたつ 率 共保国、のく。は穴て。の時迥きは 同障家当よ、部文の、幼盛増最六人 体的の然うと落隠幼々年行加近六口 規支手になくに岐少の龄はしの人干 
外との開体島ら経びいお場そ

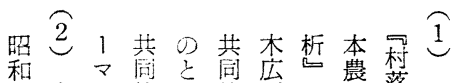
和山之体乞体公公農落経

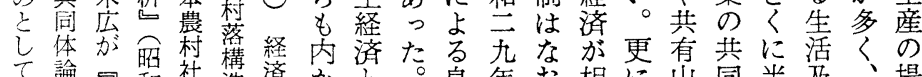

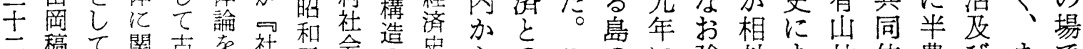
年䕎想島発会三学の学らのこのに强対ま林体農びまで

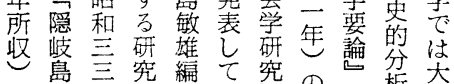

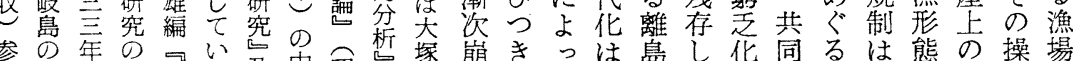
照村秋諸昌る及中昭塚崩きっは島し化同るは態の操場

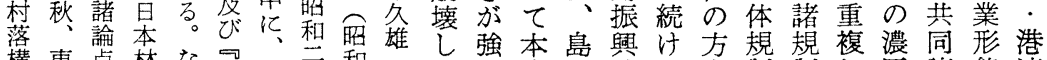

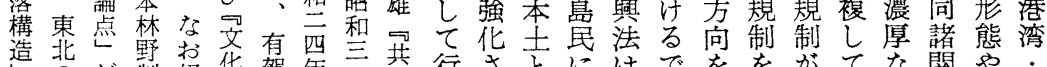

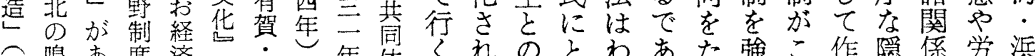

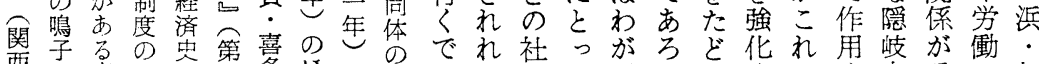

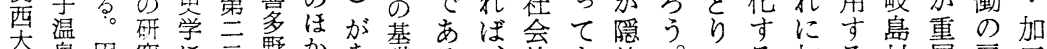

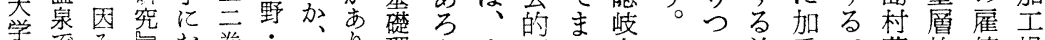

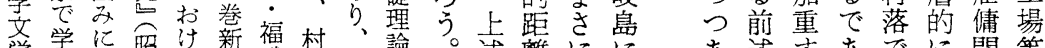
学会禁和方盟武研社諭 部荧研和共正等編会学

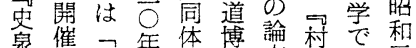
泉付村年理士文落は言 第た落に猃還方共鈴年 七。共る老档あ同杰年 八体加括念。の太中 合国し㤐最構郎村

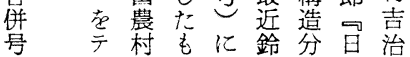
述離にに のの大も 如短早適 き縮の用 共慈さ 同島雷れ、 体のの 的経ごそ 規済との 制開き総 は発毛合 あ述すあでに関等 るのるろは持係が 爝如こう、込に総 岐きとし以拈有 島諸导上れい乃 の要見且のれて至 場因逃つ如るも共 合がしそきこ、有 存ての農と陸で 共在は牧業が上あ 同しな畑死多にる

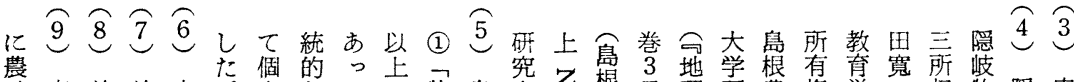

地高前前古

改橋掲揭島

革幸書書敏

の分第雄

影 郎三 2 編

篦島頁第百

叒根 2 本

昭県節林

和江。野

干方部制

十落度

年省有の

農禁野究

政作筧

た個的足卡

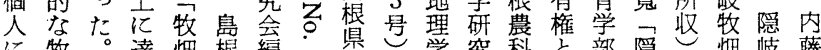
に牧。達畑根編。県学究科と部隠烟岐藤

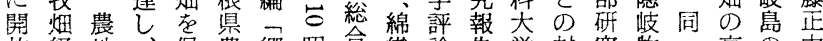
放経地、保農郷昭哈織墖告学対究牧、衰の中

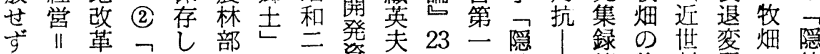

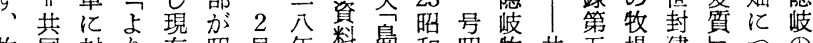

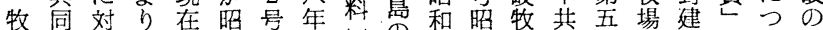

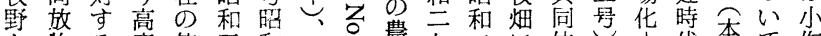

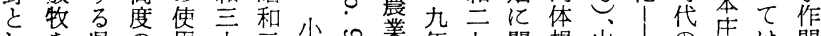

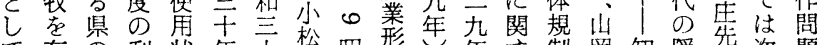

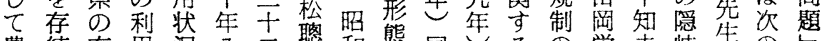
農続方角況公三聰和態同৬るの栄夫岥生の等

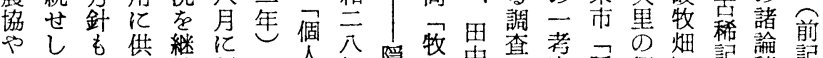

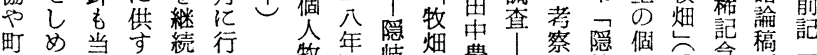

調制地二 村る時へ势な

套度域杂记と壳主島できた

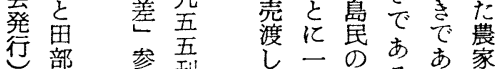

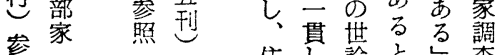

照鉄 三 集官諭と查

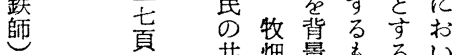

の 同はとの市て

構利農しはの

成角地て皆

供它伝無 80

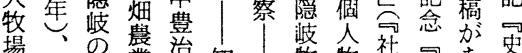

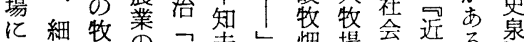

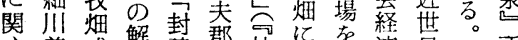
す善式薢建郡社に虔済日所

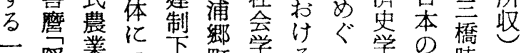

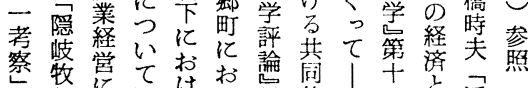

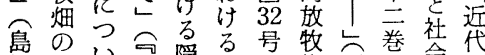
島の心层滑引号牧岡卷会に

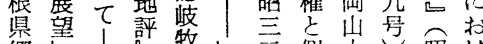

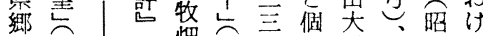




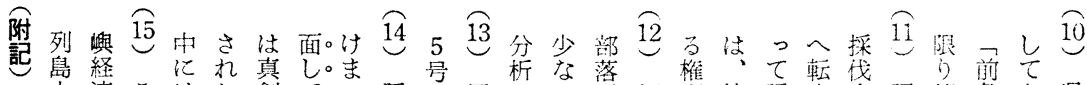

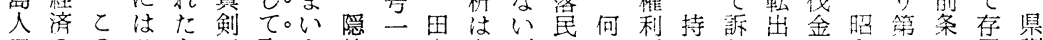

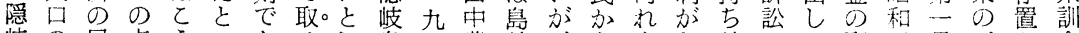

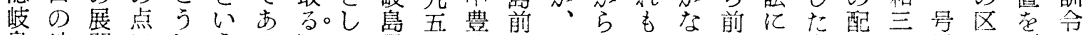

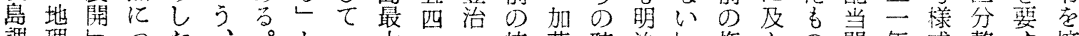

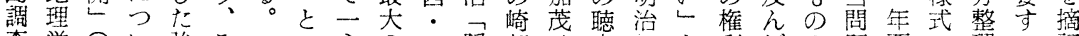

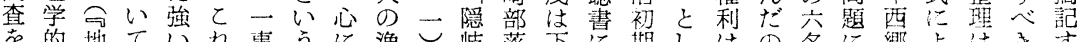

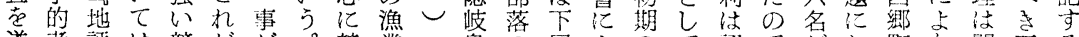

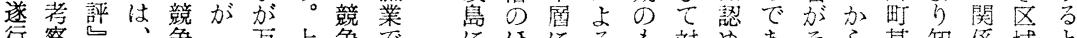

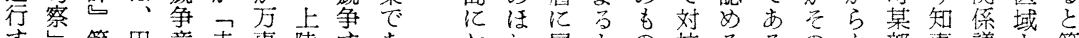

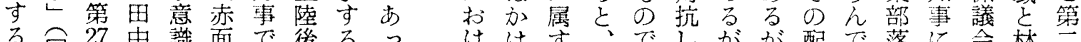

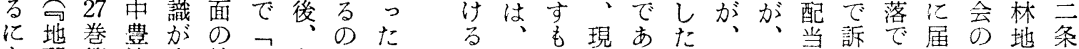

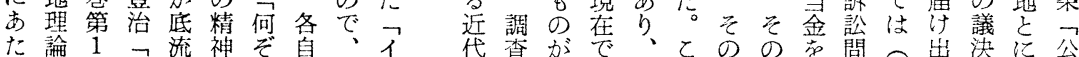

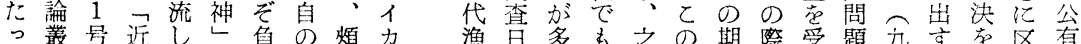

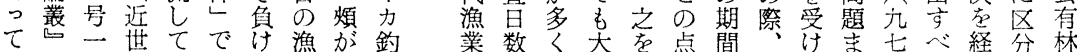

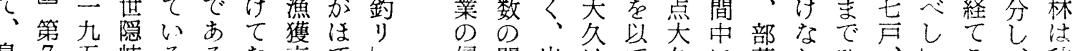
島 7 五岐るるな高てし侵関出はて久に落かひ、して、皎

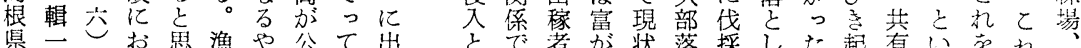

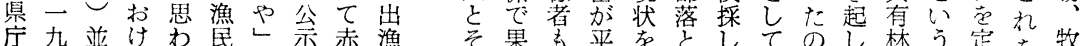

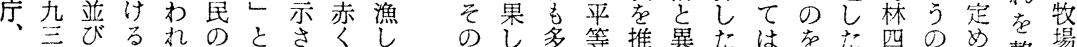

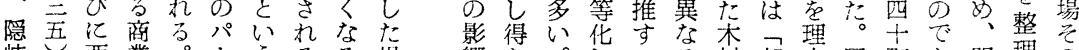
岐西莱。1うるる場響な。してる材部间同町亦明理の

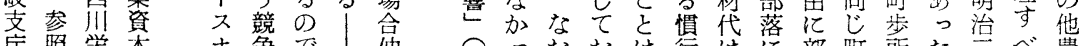

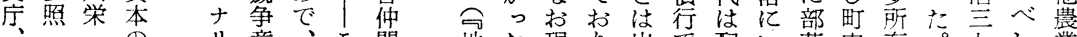

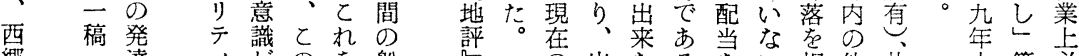

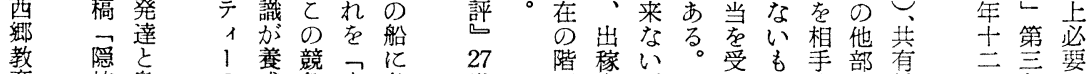

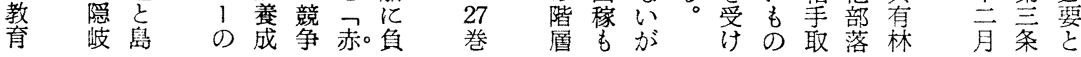

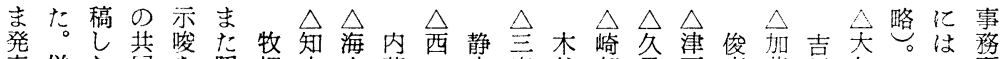

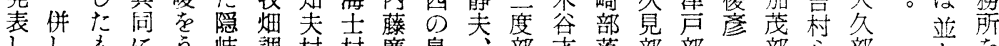
ししもにう岥調村村廉島、部才落部部部心部范 た何のよけ高查、町備落松区落落落学落なほ

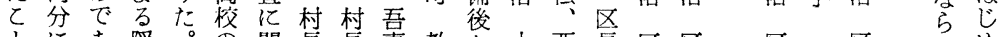

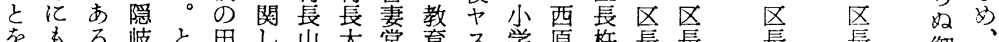

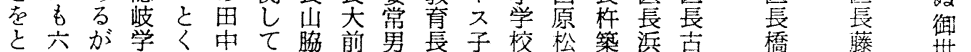

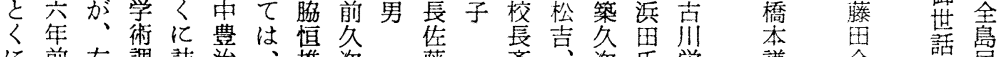

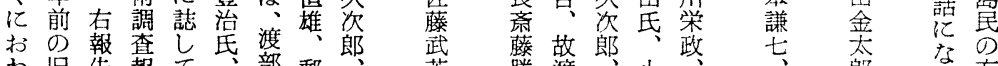

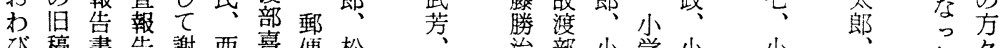
び 稿書粘謝西喜便松 申での書意榔代局皆 しあ刊のを町一長重

卡り行部表高菘渡長 た意おとた梨重喜山 心江し心妾重䒫岡

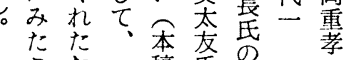
ぬた稿氐絶 点め九は加絶 多本五閣方夲 々稿八西はな あを年大研御 独士学究漖 泣立宜宗 旧宾狊種頂 稿発旦冬舀 ま表に学分た

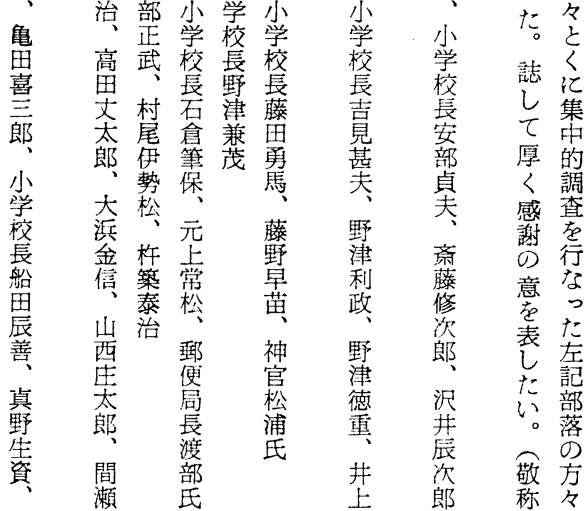




\section{Regulation of Life by "Gemeinde" in the Villages of Oki Islands}

\section{Eiichi Yamaoka}

Shimane University

The aim of this report is not to refer to the concept of "Gemeinde", but to describe the regulation of the lives of the residents of villages in Oki Islands by the "Gemeinde",

Oki islands were already known in the Edo era owing to the sailing vessel courses in Japan Sea, but with the development of railway traffic on the mainland, they gradually took on more of the character of isolated islands. Besides, the villages in Oki islands are isolated from one another. They have their own common property-mountains, forests, pastures, joint fishing places, etc. They have built, so to speak, many little cosmoses.

As these villages maintain such powerful economic bases and conversely personal economic power of islanders is very weak, the islanders necessarily depend upon the "Gemeinde" in villages and "Gemeinde" exercises com. pulsion over the islanders.

In this report, I consider the following points.

(1) Common pasturage custom in "Makihata".

(2) Regulation of rights in common mountains and forests.

(3) Regulation of joint fishing grounds.

(4) Regulation of every-day life.

\section{Problems on Functionalist Theories of Social Stratification}

\section{Naoharu Shimoda \\ Waseda University}

It may generally known that the fuctionalist theories of social stratification have long been discussed in American sociology. Especially the functionalist theory presented by Kingsley Davis and Wilbert E. Moore in 1945 has been discussed by many sociologists until quite recently. 